\title{
CONSOLIDATION OF CAPITAL IN ROMAN LAW AND ITS INFLUENCE ON THE MODERN LEGAL INSTITUTES OF THE REPUBLIC OF LATVIA
}

Summary of Doctoral Thesis for obtaining the degree of a Doctor of Law Speciality - Law Subfield - Civil Law 


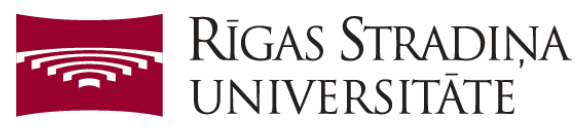

Allars Apsīis

\title{
CONSOLIDATION OF CAPITAL IN ROMAN LAW AND ITS INFLUENCE ON THE MODERN LEGAL INSTITUTES OF THE REPUBLIC OF LATVIA
}

\author{
Summary of Doctoral Thesis \\ for obtaining the degree of a Doctor of Law \\ Speciality - Law \\ Subfield - Civil Law
}

Riga, 2015 
The Doctoral Thesis developed in Rīga Stradiņš University

Research supervisor:

Dr. habil. iur., Professor Osvalds Joksts,

Rīga Stradiņš University, Latvia

Official reviewers:

Dr. iur., Associate Professor Ingrīda Veikša,

Turība University, Latvia

Dr. iur., Associate Professor Ivars Kronis,

Baltic International Academy, Latvia

Dr. iur. Anatolijs Kriviňš,

Daugavpils City Council

Defence of the Doctoral Thesis will take place at the public session of the Doctoral Committee of Legal Sciences on 18 August 2015 at 12.00 in Hippocrates Lecture Theatre, 16 Dzirciema Street, Rīga Stradiņš University.

The Doctoral Thesis is available in the library of RSU and on RSU homepage: www.rsu.lv

Secretary of the Doctoral Committee:

Dr. iur., Professor Sandra Kaija 


\section{TABLE OF CONTENTS}

ABBREVIATIONS USED IN THE SUMMARY ...................................... 4

1. GENERAL INFORMATION ABOUT THE THESIS …........................ 6

1.1. Topicality and scientific novelty of the theme ................................. 6

1.2. Questions of the research ............................................................... 8

1.3. The goal and tasks of the research ……........................................... 8

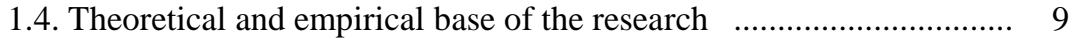

1.5. The research methods .................................................................. 11

1.6. The approbation of the results ......................................................... 11

1.7. The structure and size of the Thesis ................................................ 12

2. MAIN RESULTS OF THE RESEARCH .......................................... 14

2.1. Legislation regarding the consolidation of the capital in Roman law

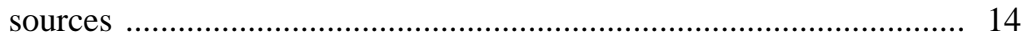

2.2. Influence of the Roman legal concepts on the modern substantive and procedural rules of the Republic of Latvia ................................ 26

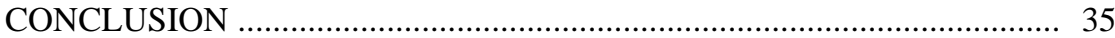

LIST OF THE SOURCES USED IN THE SUMMARY …......................... 52 


\section{ABBREVIATIONS USED IN THE SUMMARY}

A.D. - refers to a year in Common Era.

AS - "joint stock company".

BNL - refers to Associations and Foundations Law (the Law of the Republic

of Latvia, adopted on October 30, 2003).

C - refers to Roman law primary source taken from Code of Justinian part

Codex Iustinianus (534 A.D.).

CIL - refers to the material taken from no Corpus Inscriptionum Latinarum -

Berlin-Branderburg Academy of Sciences and Humanities maintained collection of Latin (wall) inscriptions (cil.bbaw.de).

CL - refers to the Civil Law (the Law of the Republic of Latvia, adopted on January 28, 1937).

CPL - refers to the Civil Procedure Law (the Law of the Republic of Latvia, adopted on October 14, 1998).

D - refers to Roman law primary source taken from Code of Justinian part

Digesta seu Pandectae (533 A.D.).

yr - ,year".

Gaius, inst. - refers to Roman law primary source from Institutes of Roman

Law by Gaius (around 161 A.D.).

c - „century”.

c A.D. - refers to century in Common Era.

c B.C. - refers to century before Christ.

I - refers to Roman law primary source from Code of Justinian part

Institutiones sive elementa (533 A.D., more- see Chapter II).

KL - refers to the Criminal Law (the Law of the Republic of Latvia, adopted on June 17, 1998)

KoL - reference to the Commercial Law (the Law of the Republic of Latvia, adopted on April 13, 2000).

KPL - refers to the Criminal Procedure Law (the Law of the Republic of

Latvia, adopted on April 21, 2005).

KS - "limited partnership".

lat. - refers to the text in Latin.

p. - "page".

LR - "the Republic of Latvia"

e.g. - "for example".

B.C. - refers to the year before Christ.

PS - "general partnership".

SIA - "limited liability company".

S. - "see".

int.al. - ,inter alia". 
etc. - "and so on".

a.o. - "and others".

vs - "versus".

\& - ,and". 


\section{GENERAL INFORMATION ABOUT THE THESIS}

\subsection{Topicality and scientific novelty of the theme}

In every society that has achieved certain degree of economic development topical becomes question about the consolidation of the capital that is in the possession of separate persons in order to gain and respectively to distribute the profit or to manage resources. The management subjects use to consolidate financial resources, means of production, knowledge and special business skills, thus sharing the risks related to the economic activity as well as profit or losses obtained as the result of the common management. Furthermore different distribution of functions of the parties of joint activity is possible some can be directly involved in the business transactions, other can only invest funds without participating in the economic activity.

The need of the consolidation principally is determined by its legal economic advantages - when consolidating the parties possess more resources, therefore they can afford to invest more funds in the technologies of manufacturing, sales or rendering of services. Possible is specialization within the particular skills of each party. Separate parties can be responsible for the different spheres of the activity - manufacturing, sales, management etc. By increasing the value of potential security, raises the interest and trust of commercial partners and lenders. By decrease of risks of the lenders, it is possible to agree on lower credit interest rates and to attract more lenders. It is possible to purchase necessary raw materials, materials or goods for sale in a bigger quantity, thus obtaining them for lower prices - a big client can more easily agree with the supplier on the supply conditions and quality criteria a.o.

Accordingly combining forces, management subjects can optimize the management of the limited available economic resources, acquiring essential advantages when competing with the others who possess smaller amount of the total resources.

The consolidation of economic resources similar to any other coordinated activity of several parties would be chaotic and difficult to carry out unless there are rules regulating this process. Usually such rules include several interactive elements - both regulations and rules issued by the state authority and behaviour rules based on society's religious and ethical principles, as well as formalized agreements worked out and mutually accepted by the involved parties under the influence of the two previous elements. All three elements should be considered equally important; however the determinative role of the regulatory base of the state authority cannot be denied.

The above mentioned fully refers also to Ancient Rome and its national economy. As it is known, within the ancient Roman civilization rather complicated and very successful legal basis was created for the successful 
functioning of the huge and for that time highly developed empire. From the information of primary sources of Roman law available to the nowadays researcher, it can be judged that the order of the consolidation of economic resources/capital possessed by the Romans as well as common management was regulated in a rather complicated and detailed way.

It must be also noted that legal principles developed by the Romans, in particular in the field of private or civil law, are so effective that they form the basis of Western and also of all global world's private law. In some parts of the world this influence is more direct - in continental Europe and in the former colonies of its countries existing so called Romano-Germanic or Continental European law, in some countries alternatively - in England and Wales, the USA and in the most of the British colonies Anglo-Saxon or Common law. As it is known, modern Latvia belongs to the Continental European law and within the reception of provisions of law and the development of the history the principles developed by the ancient Romans have been incorporated also in the legislation of the Republic of Latvia. As the result our Civil law adopted in 1937 contains rather direct influence of Roman private law. It can be maintained that for a person who is not familiar with the basic principles of Roman private law Latvian Civil law can seem to be difficult to understand and complicated to comprehend. The impact of the legal traditions started by the Romans can be observed also in substantive and procedural rules of other fields of law, which can be perceived much better by being aware and understanding the Roman source of legal ideas incorporated in them.

Accordingly the author considers it to be his duty to facilitate thorough study of primary sources of Roman law, in particular legislation regarding the consolidation of economic resources/capital and the order of common management and the impact of Roman legal principles on the development of the modern legal institutes incorporated in the law of the Republic of Latvia.

The choice of the theme for the research was determined also by the author's previous work experience and special academic interest, by lecturing on study courses „Roman civil law” and „Commercial law” for more than 10 years.

Besides according to the information in the author's possession Latvian researchers have not yet in particular studied the current theme from this perspective; the author has not found publications in the Latvian language. Accordingly the current research could provide certain contribution to the development of the national field of law. 


\subsection{Questions of the research}

Within the research the author has put forward following questions of the research:

1. Whether the sources of Roman law contain comprehensive and complicated, determined by the economic needs of the society and provided by the rather high level of economic development, legislation on the consolidation of the economic resources/capital in the possession of individuals and on the order of common management?

2. Whether the impact of the legal concepts developed by the Romans can be observed in substantive and procedural rules of different fields of law of the Republic of Latvia?

\subsection{The goal and tasks of the research}

The goal of the research - to study and to analyse information contained in the primary sources of Roman law regarding legislation on the consolidation of the economic resources/capital and the order of common management, together with analysing the impact of such legislation on the legal institutes of current Republic of Latvia.

Following tasks are established in order to achieve the goal of the research:

1) to evaluate the economic preconditions of the development of the Roman legislation on the consolidation of the economic resources/capital and the order of common management;

2) to identify and summarize primary sources of Roman law on the consolidation of the economic resources/capital and the order of common management;

3) to analyse legal regulation of the general principles of establishment and functioning of the Roman partnership or partnership contract (societa - lat.);

4) to analyse the legal regulation regarding legal status of the property of the Roman partnership, the order of investment, management and alienation of the property;

5) to analyse the legal regulation regarding the order of distributing the profit, covering the losses and the order of compensation of the expenses of a partner in the Roman partnership (societa - lat.);

6) to analyse the regulation regarding legal status, representation and liabilities of the Roman partnership (societa - lat.);

7) to analyse the regulation regarding legal economic status of partners of Roman partnership (societa - lat.), their mutual relationship and change of their structure; 
8) to analyse the regulation regarding legal interaction of the Roman partnership (societa - lat.), Roman marriage, inheritance and arrogation institutes;

9) to analyse the regulation regarding the time -limits and cease of operation of the Roman partnership (societa - lat.);

10) to analyse the regulation regarding the possibilities of the partners of the Roman partnership (societa - lat.) to force their partners in a legal way to fulfil their liabilities and to achieve protection of violated interests;

11) to analyse the regulation regarding establishment and functioning of the Roman corporative bodies - associations (universitatis - lat.), collegiums and corporations;

12) to evaluate the impact of the above mentioned regulation on the legal institutes in the modern Republic of Latvia, by analysing ideological interconnection between primary sources of Roman law and modern Latvian legislation.

\subsection{Theoretical and empirical base of the research}

Roman law primary sources analysed in this research are principally obtained from the so called Code of Justinian ${ }^{1}$ or Corpus Iuris Civilis (lat.)

${ }^{1}$ Codification is made from 528 A.D. till 534 A.D., it is linked with the political activities of the emperor of Eastern Rome or Byzantium Justinian I (Flavius Petrus Sabbatius Justinianus Augustus, 483 A.D. - 565 A.D.). Codification was supervised by the jurist, chief of Justinian private office Tribonian (Tribonian, around 500 A.D. - 547 A.D.). (see Jolowicz; Nicholas 1972). Consists of four chapters (see Kalniņš 1977):

I. Codex Iustinianus - contains laws (constitutions) issued by emperors starting from the emperor Hadrian (Publius Aelius Trajanus Hadrianus Augustus, 76 A.D. - 138 A.D.) till the very Justinian. The first version accomplished in 529 A.D., it is not available nowadays. The second version Codex repetitae praelectionis (lat.) issued in 534 A.D. It consists of 12 books (liber-lat.) which are divided into chapters with headings - titles and fragments, which in their turn can consist of paragraphs. Traditional example of citing: C 4.37.1 or C 4.38.12.1

II. Digesta seu Pandectae - the selection - ,arrangement or collection” of jurists works of classical period (I - III c A.D.) (see Watson 1985), issued in 533 A.D. It consists of 50 books which are divided into chapters with headings - titles and fragments containing paragraphs. An introductory text - principium (lat., „beginning”), abbreviated as ,pr" can be included before the paragraph 1. Traditional example of citing: D 17.2.3 pr. or D 17.2.3.3

III. Institutiones sive elementa - Code of Justinian. Supposed to be a simple textbook on legal concepts at the same time having effect of legal rule (see Birks ; McLeod 1987), issued in 533 A.D. together with Digest. Its basis - around 2/3 of the text are Institutes of Roman Law by Gaius, jurist of classical period (I - III c A.D.) (Gaius, acted from 130A.D. - 180 A.D.) Consists of four books, divided into chapters titles which are divided into paragraphs, an introductory text - principium (lat., 
(Krueger 1906/ Krueger ; Mommsen 1928/ Schoell ; Kroll 1959), analysing in detail - its part Codex Iustinianus book 4, title 37 Pro socio (C 4.37.0.) (see Krueger 1906), part Digesta seu Pandectae book 3, title 4 Quod cuiuscumque universitatis nomine vel contra eam agatur (D 3.4.0.), book 17, title 2 Pro socio (D 17.2.0), book 47, title 22 De collegiis et corporibus (D 47.22.0.) (see Krueger ; Mommsen 1928) and part Institutiones sive elementa book 3, title 25 De societate (I 3.25.) (see Krueger; Mommsen 1928) anyway regulated questions regarding the consolidation of the resources in the possession of the persons in order to achieve certain economic aims. According to the author's assessment, the above mentioned parts contain $50 \%$ of rules included in the Code of Justinian regarding the order of consolidation of economic resources and common management with the intention to gain profit. The remaining 50\% can be found in the very broad text of the code in the form of separate text fragments (see Krueger 1906/ Krueger ; Mommsen 1928), that inter alia complicates the summarizing and analysing of those rules. At this point the author benefited from the technical possibilities provided by the modern technologies in the field of information processing.

Besides separate fragments from Institutes of Roman Law by Gaius (Gai Institutiones - lat.) (see Būmanis 1938) - Book III, paragraph 148.-154 (Gaius, inst. 3.148. - Gaius, inst. 3.154.) are used (see Seckel; Kuebler 1903).

In total 603 primary sources of Roman law are processed and analysed in the Thesis. The summary of primary sources of Roman law analysed in the Thesis are indicated in the list of the sources.

By analysing ideological interconnection between primary sources of Roman law and modern Latvian legislation, following laws were studied: Associations and Foundations Law (LR law, adopted on October 30, 2003), Civil Law (LR law, adopted on January 28, 1937), Civil Procedural Law (LR law, adopted on October 14, 1998), Criminal Law (LR law, adopted on June

„beginning”), abbreviated as „pr” can be included before the paragraph 1. Traditional example of citing: I 3.25 pr. or I 3.25 .3

IV.Novellae - law issued by Justinian after approval of Code and Digest novellae leges (lat., „new laws”). Issued in 535 A.D.-565 A.D., issued in one collection after the death of Justinian. Each novel has an introduction (praefatio - lat.), the text of law is divided into chapters (caput-lat.) with or without paragraphs and epilogues (epilogos). Traditional example of citing: N 89.cap.12.6

Codification is not preserved till nowadays as the united original document from the period of Justinian, what are preserved are transcripts of separate parts. Codification is known under the title „Corpus Iuris Civilis", for the first time such title appears in 1583 as a heading for the first united edition of the Code of Justinian done by the lawyer and professor of law Dionysius Gothofredus (1549 A.D. -1622 A.D.) of the French origin at that time being very famous in France, Switzerland and Germany. (Kunkel 1966) 
17, 1998), Commercial Law (LR law, adopted on April 13, 2000) and Criminal Procedural Law (LR law, adopted on April 21, 2005).

\subsection{The research methods}

Following research methods were applied in the research: Historical applied to analyse and to observe dynamics of the development of legal institutes of the ancient Romans and modern Latvia. Method of comparison applied to analyse features common and distinct of legal institutes of the ancient Romans and modern Latvia. Analogical - knowledge about features of legal institutes of modern Latvia are gained on the ground that they are similar to the legal institutes of ancient Romans and vice versa. Deductive - following the general aspects of the legal conceptions of legal institutes of the ancient Romans and modern Latvia conclusions were made regarding individual features of legal institutes developed within those conceptions. Inductive - used in order to show and analyse concretization of rules and general principles of law of the ancient Romans and modern Latvia performed by persons applying the law.

\subsection{The approbation of the results}

Research results are approbated during the time period from 2012.2014., by reflecting/presenting them in the following scientific publications and conferences.

1. Apsitis, A. (2014) The reimbursement for the medical treatment expenses within the framework of Roman Partnership Agreement (Societa). SHS WEB Conferences 10 00003, DOI: http://dx.doi.org/10.1051/shsconf/20141000003, viewed 19.09.2014.

2. Apsìtis, A.; Joksts, O. (2013.) A Crime - theft (furtum) within the context of Roman law, Administratīvā un Kriminālā Justīcija., 1 (62), 7-14, 11, ISSN 1407-2971.

3. Apsitis, A.; Joksts, O. (2013) The concept of infamy (infamia) in Roman law: An engine for sustainable development and public security - the Roman example, Journal of Security and Sustainability Issues 3(1):, 32, 31-41 http://dx.doi.org/10.9770/jssi.2013.3.1(4) , 34, 33-43, ISSN 2029-7017/ISSN 2029-7025 online.

4. Participation in the international scientific conference „Topical problems of innovative law" organized by Riga Stradiņš University Faculty of Law (Latvia), Academy of Law of Tallinn University (Estonia), Mykolas Romeris University (Lithuania) and the Institute for Security and Development Policy (Sweden) on April 25, 2013 in Riga. The theme of the paper: „Roman 
legal principles within the law of the Republic of Latvia. Partnership agreement (Societa)".

5. Participation in the international scientific conference „4th International Interdisciplinary Scientific Conference PARTNERSHIP HELTH WELFARE" organized by Riga Stradiņš University, Association of Clinical Social workers, the Union of Latvian Rehabilitation Professional Organizations, Latvian Association of Audio Speech Therapists and the State Medical Commission for the Assessment of Health Condition and Working Ability on November 22, 23, 2012 in Riga. The theme of the paper: „The reimbursement for the medical treatment expenses within the framework of Roman Partnership Agreement (Societa)". Theses of the paper are published: 4th International Interdisciplinary Scientific Conference „Partnership. Health. Welfare". 1th Conference of Speech Therapists (Riga, November 22-23, 2012): Abstracts.- Riga: Rīga Stradinš̌ University, 2012. - 16, 17 p. ISBN 978-9984793-19-1.

6. Participation by presenting the paper (co-author) in the scientific conference organized by Riga Stradinš University on March 21, 22, 2013 in Riga. The theme of the paper: „Litigation regarding claim deriving from a partnership agreement (actio pro socio) and transformation of ancient Roman legal principles in modern law”. Theses of the paper are published: Riga Stradinš University scientific conference of 2013: Abstracts (Riga, March, 21, 22, 2013). - Riga, Riga Stradinš̌ University, 2013, - 417 p., ISBN 978-9984793-24-5.

\subsection{The structure and size of the Thesis}

The Thesis consists of eight chapters. In the First Chapter preconditions for the development of Roman rules of the consolidation of the resources/capital and the order of common management determined by the economic needs of Ancient Rome society and the level of economic development are analysed.

In the Second Chapter primary sources of Roman law regarding the consolidation of the economic resources/capital and the order of common management are identified.

In the next chapters following issues are analysed: legislation regarding the general principles of establishment and functioning of the Roman partnership or partnership contract (societa - lat.), the legal status of the property, the order of investment, management and alienation of such property; order of the profit distribution, covering of losses and compensation of partner's expenses (the Third Chapter), legal status, representation and liabilities of the partnership (the Fourth Chapter), legal economic status of partners of the partnership, their mutual relationship and change of their structure; legal interaction of the institute of partnership and marriage, the 
partnership and inheritance, partnership and arrogation (the Fifth Chapter); the time-limits and cease of operation of the partnership (the Sixth Chapter), the procedural aspects of litigation regarding a claim deriving from a partnership contract (actio pro socio) (the Seventh Chapter).

The Eighth Chapter is devoted to the analysis of the regulation regarding the establishment and functioning of the Roman corporative bodies - associations (universitatis - lat.), collegiums and corporations (collegiis et corporibus - lat.).

Within the above mentioned chapters ideological impact of the studied Roman rules on the modern Latvian legal institutions is analysed.

In order to optimize the understanding of the material included in the text, in the explanations given in the footnotes inter alia the meaning and essence of the separate Roman law institutes as well as concepts related to the culture and the legal order of Ancient Rome are additionally explained. For this purpose 71 footnote in total is included. 


\section{MAIN RESULTS OF THE RESEARCH}

In the result of realization of the research goals and tasks, the author puts forward following theses for the defence:

\subsection{Legislation regarding the consolidation of the capital in Roman law sources}

Theses regarding the research question 1 :

„Whether the sources of Roman law contain comprehensive and complicated, determined by the economic needs of the society and provided by the rather high level of economic development, legislation on the consolidation of the economic resources/capital in the possession of individuals and on the order of common management?":

1. The economic needs of the partnership of Ancient Rome determined the necessity, but the level of the economic development contained the corresponding preconditions for establishing rather complicated and detailed rules on the consolidation of the economic resources/capital.

1.1. The rather high development level of Ancient Rome national economy and active economic life, in particular in the I-III century A.D. inter alia is characterized by the rather high level of the consumption in the region of the Mediterranean Sea (Scheidel et al. 2007), by the total amount of population of the region (Scheidel 2006) and its positive growth dynamics (Scheidel et al. 2007), by the growth of population proportion involved in the non-agriculture production and providing services (Temin 2001), by the increase in the productivity of the work of those involved in the manufacturing and by the increase of the amounts of the levied taxes and ground-rent in the terms of money (Hopkins 1980), as well as by the increase in volumes of trade, including long-distance trade (Duncan-Jones 1990).

1.2. The development of national economy, the economic activity creates the necessity for legal institutes regulating such activity, but the existence of the effective legal institutes facilitate the development of the economy. Thus for its rather complete and optimal nature Roman private law can be thankful to the successful development of Ancient Rome and its economy, but Roman legal institutes should be recognized as one of the essential factors making such development possible (Apsītis; Joksts 2013). Let's just mention private property rights in respect of the means of production, including the land guaranteed in the Roman legal tradition (See I.2.1.4; I.2.1.20; I.2.1.21; I.2.1.22 a.o. / CIL 11.1147; Duncan - Jones 1990)).

1.3. The economy of Ancient Rome was characterized by the fact that strategically important, large-scale transactions were carried out by private sector (Rickman 1980), public procurements were placed at private contracting 
parties (Sirks 1991), together with determining liability for malicious increase of the supply costs (D 48.12.2 pr.; D 48.12.2.2) and fulfilment of measures directed at increase of false deficit/prices (D 48.12.2.1), by in every possible way supporting spreading the information about such kind illegal activities (D 48.12.1; D 48.12.3.1).

1.4. Very often the resources necessary to carry out economic projects of the large-scale were possible to be obtained only when several businessmen joined together, thus accumulating finances, skills, technological equipment and other necessary resources, as well as decreasing possible risks. The businessmen of Ancient Rome were not an exception. For example, Plutarh in his work „Plutarh's Lives” (Vitae parallelae - lat.) speaks about seamen unions in the field of sea shipments (Plutarch 1899). Partnerships (societas - lat.) of the seamen were established, they continued to exist also after the death or bankruptcy of one or another partner (Sirks 1991).

The consolidation of such resources and efforts would be burdensome, if not impossible, without corresponding legislation, without rules approved and guaranteed by the state authority.

2. References in respect of the order of the consolidation of the resources/capital are found in the paragraphs $148-154$ of Book 3 (Gaius, inst. 3.148. - Gaius, inst. 3.154.). of the Institutes of Roman Law by Gaius (Institutiones - lat.) who was the Roman jurist (Gaius, acted from 130 A.D. 180 A.D.). However the main source of law regarding the ancient Roman rules on the consolidation of the capital is so called Code of Justinian or Corpus Iuris Civilis (made from 528 A.D. till 534 A.D.). However the main source of law regarding the ancient Roman rules on the consolidation of the capital is so called Code of Justinian or Corpus Iuris Civilis. Codification part Codex Iustinianus book 4, title 37 Pro socio (C 4.37.0.), part Digesta seu Pandectae book 3, title 4 Quod cuiuscumque universitatis nomine vel contra eam agatur (D 3.4.0.), book 17, title 2 Pro socio (D 17.2.0), book 47, title 22 De collegiis et corporibus (D 47.22.0.) and part Institutiones sive elementa book 3, title 25 De societate (I 3.25.) regulated issues regarding the consolidation of the resources in the possession of the persons in order to achieve economic goals. Here can be found $50 \%$ of rules regarding the consolidation of economic resources and the order of collective management. The remaining 50\% are scattered in the very text of code in the form of separate text fragments.

3. Two organisational legal forms of the consolidation of the resources/capital can be distinguished:

i) Roman partnership or partnership contract (societa - lat.),

ii) Roman corporative bodies (,legal entities”) associations (universitatis - lat.), collegiums and corporations (collegiis et corporibus -lat.).

4. Reglamentation of the general principles of the Roman partnership or partnership contract (societa - lat.) includes the conditions regarding the 
time-limits of the partnership's activity and time-limits within which the partnership contract entered into force (D 17.2.1.pr.), the partnership contract as a mandatory precondition for the existence of the partnership (D 17.2.32; D 10.3.2 pr.), legal status of the contract - a contract (contractus - lat.) (D 50.16.19) \& consensual contract (D 44.7.2 pr.), necessity to depict the true will of the contracting parties, prevention of fraud (dolo malo -lat.) and compliance with the principle of good faith (bona fides -lat.) (D 17.2.3.3; D 4.4.16.1), provisions on the essential terms of the contract (D 44.7.2.1), the form of partnership contract (D 17.2.4 pr.; D 44.7.2.1; D 44.7.2.2; C 8.17.11 pr.), inclusion of conditions (C 4.37.6), goals, tasks and kinds of the partnership activity (D 17.2.5. pr.; D 29.2.45.2; D 19.5.13.1; D 21.1.44.1; D 28.5.60. (59.) 1; D 39.4.3.1; I 3.25 pr.), right of the contracting parties to contribute work performed for the benefit of the partnership (D 17.2.5.1; C 4.37.1), situation of the female contracting parties in the partnership contract (D 16.1.17.2; D 16.1.1 pr.), restrictions and prohibitions in respect of the separate kinds of the partnership contract, aims and intentions for concluding the contracts (D 17.2.5.2; D 39.6.35.5; D 38.1.36; D 44.5.1.7; D 17.2.35; D 17.2.57; D 18.1.35.2; D 46.1.70.5; D 27.3.1.14; D 48.10.1 pr.), provisions of shares of each partner and principles of sharing impact among the partners (D 17.2.29 pr.; D 17.2.80.; D 17.2.75; D 17.2.76; D 17.2.77; D 17.2.78; D 17.2.79; D 17.2.6).

5. The partners of the Roman partnership (societa - lat.) did not lose ownership regarding the contributed property - they became co-owners in respect of the joint fund of the partnership (D 19.5.13.1). The partners were able to force their co-partner to invest due things in the partnership, by bringing a claim against him arising from the partnership contract (D 17.2.74). If the aim of the partnership was to sell the consolidated property, the partnership dissolved in case part of this property was lost; if the aim was common management of the property - the contract was still valid (D 17.2.58 pr.). In case the property contributed by the partner was lost after the moment of investing it in the partnership, losses were incurred jointly to all partners, if before - only to unlucky partner (D 17.2.58.1). One could not claim from the partnership what was lost due to gambling (alea - lat.) or due to breach of the marriage, but it was possible to regain the property that was lost because of the malicious intention (dolo - lat.) of other partners (D 17.2.59.1). Contributions of an illegally obtained property were forbidden (D 17.2.53; D 17.2.52. 17), however, if such a property was added to the common fund of the partnership, it was presumed, that it has become a part of the joint property and should be considered as the common gain (commune erit lucrum - lat.) of the partners (D 17.2.53) - the investor could remove it only in the case if an action against him was brought regarding returning of the misappropriated property (D 17.2.54) - one should return illegally possessed property or such property and penalties. If the co-partners were not aware of the illegal investment, the 
guilty one was liable on his own, if they were aware - they also had to pay the penalty ( $\mathrm{D}$ 17.2.55; $\mathrm{D}$ 17.2.56). If under the partnership contract all the property belonging to the parties should have been contributed, the partners were co-owners of the whole property (D 17.2.1.1; D 17.2.2). The debts of the parties remained, but the right to claim against separate debtors of the partners were transmitted to the partnership (D 17.2.3 pr.). Heritages, legates, gifts and other future properties were obtained jointly (D 17.2.3.1) - it referred also to any property obtained in the future (D 17.2.73 pr.; D 17.2.3.2). The partner preserved his right to indicate his heirs in the testament (C 6.22.1 pr.) The partnership was liable to its partner for damages and harm done to him (D 17.2.52.16), it had to repay to him penalties imposed on him, however only in the case when the partner was sentenced without reason (D 17.2.52.18), and repay amounts spent for the benefit of partner's children (D 17.2.73.1), as well as debts by testator of the partner- co-legatee in favour of the state (rei publicae debita - lat.) (D 10.2.39.3). As regards the partnership contract without a rule to invest the whole property private debts of the partners did not refer to the partnership and were not binding to it unless they did not derived from the economic activity of the partnership. (D 17.2.12). The partnership had no rights regarding heritage, legates and gifts meant for its partners (D 17.2.9; D 17.2.10; D 17.2.11; D 17.2.71.1; D 29.2.45.2 ), however the salary and other remuneration of partners should have been contributed in it (D 17.2.52.8). If not provided otherwise, it was supposed that the contract automatically includes any growth/profit gained from the economic activity of the partnership (D 17.2.7). The profit included everything arising from the diligence of the partner (D 17.2.8). The partner had rights to get only that profit in which increase he has participated (D 17.2.13). Even in the partnership with a demand to invest all the property, the partner had no rights to alienate on this own the amount that is bigger that the value of his share (D 17.2.68 pr.). In case of the agreement not to divide the property of the partnership, it was not allowed to sell the property or treat it in a way that could be considered as a division of the property (D 17.2.16.1; D 17.2.17 pr.) - the sale as such was not completely forbidden - only in the situations when it would mean actual division of the property (D 17.2.16.1).

6. The partner had to invest in the common fund of the partnership all what he gained (D 29.2.45.2), but the common profit of the partnership was to be distributed among the partners correspondingly (D 22.1.38.9). If the principles of the division of the profit and losses were not stipulated, profit was dividend and losses were covered on equal ground for all the partners (I 3.25.1; C 4.37.3), in case such provisions on division were stipulated in the contract, they should have been observed (I 3.25.1). In case provisions regarding share in profit or the part of losses to be covered by each partner were stipulated, it was supposed that the amount of the latter is the same as the amount of the former (I 3.25.3). Separate partners could be exempted from 
covering the losses (I 3.25.2) - in case the value of the services provided by him corresponded to the part of losses he was exempted from (D 17.2.29.1). It was possible to stipulate in the contract different provisions in respect of each partner and the amount of the profit he is entitled to and the amount of losses he is supposed to cover (I 3.25.2), by observing the principle of proportional division of profit and losses among them (D 17.2.30). It was not allowed to establish the partnership in which one of the parties was covering only losses without participating in the profit (Leonine (lat.) - "Lions" - from a fable of fabulist Phaedrus (Phaedrus, around 15 B.C.- around 50 A.D.) (see Riley; Smart 1887)) (17.2.29.2). In the partnership established for a special business activity purposes the partners were entitled only to the profit deriving from this activity (D 17.2.52.5; D 17.2.52.6). Interest in respect of the given loan was to be divided among the partners only in the case if the loan was given on behalf of the partnership (D 17.2.67.1). If a partner tried to hide the profit or to misappropriate it, he should return it by paying penal interest (D 17.2.60 pr.). The rights of heirs to receive share of profit of the predecessor were provided (C 4.37.3). Similar as in the case with the profit, losses incurred by a partner were to be divided among all partners (D 17.2.52.4). Losses were to be shared if they arose due to force majeure (Vis maior, quam Graeci veou bian appellant - lat.) (D 19.2.25.6) - events that could not be influenced by a person and ,it was not possible for a man to resist them" (maiore casu, cui humana infirmitas resistere non potest - lat.) (D 44.7.1.4). The partners were entitled to compensation for expenses covered for the benefit of the partnership. (D 17.2.38.1) - they could ask for reimbursement from co-partners (D 17.2.67 pr.). For example, the sources speak about the reimbursement of reasonable travelling expenses, expenses for tiding out the stream (rivum - lat.) that is common property of the partners a.o expenses (D 17.2.52.15; D 17.2.52.12; D 17.2.52.10; C 8.10.4; D 3.5.39; C 4.37.2; D 39.2.32). Together with reimbursement of expenses the partners were entitled to collect interest both for investing their money (the same \% rate as in the case of lending money) and borrowed money (D 17.2.67.2; D 17.2.52.10; C 8.10.4; C 8.10.5). Provisions in respect of the medical expenses were determined - e.g. expenses regarding treating injury got when trying to prevent attempt of the escape of the partnership's slaves (D 17.2.60.1; D 17.2.61) or payment to the doctors after being caught by the robbers (D 17.2.52.4). (Apsitis 2014)

7. As regards legal status, representation and liability for obligations of the Roman partnership, emphasized should be Digesta book 46, title 1 in which it is indicated that the partnership, similar to mass of succession or municipality are able to act legally in the same way like natural persons (D 46.1.22). The sources also say that the partnership can have a leader (magister - lat.), who is entitled to undertake obligations on the behalf of it and those obligations are binding to the partnership's business partners (D 2.14.14). However, the partnership contract (societa - lat.) cannot be regarded as a 
valuable corporative body - the partners were not only responsible for its liabilities with all their property (D 17.2.63 pr.; D 17.2.67.3; D 17.2.27; D 17.2.28; D 17.2.63.4; D 17.2.63.1; D 17.2.63.3; D 17.2.63.2; D 17.2.63.8; C 1.12.2-6; C 1.12.6.8; D 45.2.2; D 46.1.71 pr.; D 45.2.10; D 16.3.1.6; D 45.2.9.1), but this was also fully joint liability - creditors of the partnership were entitled to bring an action not against the partnership as a corporative body but against each of the partners, besides usually (regarding exceptions see for example D 14.1.4 pr.) not proportionally to his share in the partnership but for the debt of the partnership in total (D 14.1.1.25; D 14.1.4.1; D 14.1.4.2; D 14.1.6.1; D 14.3.13.2; D 14.3.14). At the same time it is indicated that the debts obtained during the existence of the partnership, should be covered from the common fund of the partnership (D 17.2.27) and the partner is entitled to claim from his co-partners his part (D 14.1.3; D 14.3.13.2; D 14.3.14). If the partner was not willing to be involved in the obligation by the co-partner, he should have clearly expressed such his will (D 3.5.7.3). To undertake obligations on the behalf of the partnership could both the very partners (D 2.14.27 pr.; D 14.1.5.2; D 2.14.25 pr.; D 2.14.24), and representatives appointed by them - e.g. a captain of a ship (magister navis - lat.) (D 14.1.4.1; D 14.1.1.15; I 4.7.2.; D 14.1 tit.; C 4.25 tit; D 14.1.1 pr.; D 14.1.1.17; D 14.1.1.24; D 14.1.1.25; D 14.1.2; D 14.1.5.2; D 14.1.3; D 14.1.1.1; D 14.1.1.2; D 14.1.1.3; D 14.1.1.7; D 14.1.1.12; D 14.1.1.13; D 14.1.1.14; D 14.1.1.5 ; D 14.1.1.4; D 14.1.4.2 ; C 4.26.12 ; D 17.2.24 ; D 14.1.6 pr. ; D 14.1.1.20; D 14.1.6.1; D 14.1.4 pr. ), commercial agent, manager of a commercial or industrial company (institor - lat.) (D 14.3.13.2; D 14.3.tit.; C 4.25 tit; D 14.3.1; D 14.3.6; D 14.3.1; D 14.3.2; D 14.3.5.11; D 14.3.5.12; D 14.3.3; D 14.3.4; D 14.3.5 pr.; D 14.3.18; D 14.3.5.1-10; D 14.3.5.10; D 14.3.11.6; D 14.3.1; D 14.3.19.1; D 14.3.14; D 14.3.6; D 14.1.1.20), the above mentioned leader (magister - lat.) (D 2.14.14 ). The representatives could be chosen among the partners (D 14.1.4.1), as well as persons not being partners. They could be both free persons and slaves belonging to its partners or third parties (D 14.1.1.4.; D 45.3.28.1; D 45.3.28.3; C 4.26.12; D 15.1.11.9; D 14.1.1.20; D 16.2.9 pr.; D 16.2.9.1; D 15.1.27.8; D 15.1.51; D 15.1.15; D 15.1.11.9; D 15.1.13; D 15.1.27.8; D 15.1.20; D 15.1.19.2; D 15.3.1 pr.; D 15.3 tit.; D 15.3.13; D 15.3.14; D 9.4.1 pr; D 9.4.2 pr.; D 9.4.8; D 9.4.9; D 9.4.10; D 10.3.15; D 47.6.1 pr.; D 47.6.2; D 47.6.1.1; D 47.6.5). The partners of the partnership were jointly liable for the obligations undertaken by their representatives (D 14.1.4.1; D 14.1.6.1; D 14.3.13.2; D 14.3.14). Very often Roman partnerships were established with the aim to trade with slaves (D 21.1.44.1; D 21.1.1 pr.; D 21.1.1.2; D 21.1.1.1; D 21.1.44.1). The same as traders of slaves, also collectors (publicani -lat.) of Roman taxes used to establish partnerships for common tax collection (D 17.2.5. pr.; D 39.4 tit.; D 50.15 tit.; D 50.16.16; D 39.4.1 pr.; D 39.4.3 pr.), in which co-partners were liable for illegal activities of a tax collector (D 39.4.3.1.). In case anybody 
without authorization became a voluntary agent of the partnership (commenced to do so called the action on uncommisioned agency - negotiorum gestio (lat.)) and one of the partners allowed that, but the other one did not, the claim regarding reimbursement of the expenses related to this action on uncommisioned agency (negotiorum gestorum actionem - lat.) can be brought only against the partner who allowed this activity. Transactions concluded by this person were binding to all partners (D 46.8.1). If this person promised to one of the co- partners that the creditor will approve the fact of fulfilment of the obligation, this approval (ratification) referred also to co-partner (D 46.8.14).

8. The principle of justice should have been observed in the mutual relations among the partners of the Roman partnership. „Good faith” (bona fides - lat.) was essential part of a claim deriving from the partnership contract (D 17.2.52.1), before the court the case was heard by taking into account the actual circumstances, eliminating any fraud and unjust action. A partner was liable for the losses his co-partners would suffer due to his neglect (neglegentia eius - lat.) (D 17.2.25; D 17.2.26). If the partners were blamed for neglect of the same level and value (parem neglegentiam - lat.), off-set was applied in respect of claims among them (D 16.2.10 pr.; D 16.2.10 1). The partners were liable both for intentional damage (dolus - lat.) and for negligence (culpa - lat.) (D 50.17.23; D 13.6.5.2; D 17.2.52.2; D 17.2.52.11; D 17.2.68.1; D 17.2.72; I 3.25.9). This provision was valid if the parties had not agreed on other (higher or lower) - „vel plus vel minus”(lat.)) limits of the liability (D 50.17.23). The mutual liability did not include accidental event (casus - lat.) An exception special provision on a contract of bailment - increased liability of a hotelkeeper, owner of the ship and keeper of the resting-place (limit - also occasional case (casus - lat.)) for keeping property (see D 4.9 tit.; D 4.9.6.1). The partners were not liable for unpredictable accidents (imprudentibus accidunt-lat.) (D 17.2.52.3) or so called force majeure (vis maior - lat.) cases (D 50.17.23), which could not be influenced by the responsible party and therefore was exempted from this liability (Vis maior, quam Graeci veou bian appellant - lat. (D 19.2.25.6)/ maiore casu, cui humana infirmitas resistere non potest - lat. (D 44.7.1.4)). When claiming liability for delicts (e.g. a theft (furtum - lat.), illegal action (iniuria - lat.) a.o. ), an action against the guilty partner could be brought both in respect of a committed delict and the breach of the partnership contract (D 17.2.45; D 47.2.45; D 17.2.46; D 17.2.47.1; D 17.2.48; D 17.2.49; D 17.2.51.1; D 47.10.17.9; D 48.18.17.2). When being liable for so called quasidelicts (quasi delictum - lat.) (damages to property and bodily injuries caused due to throwing out/pouring out articles/liquids) the partners - owners of the building/apartment, tenants, inhabitants could claim from the co-partners proportional compensation - regarding amounts any of them have paid to a victim (D 9.3.1pr.; D 9.3.1.10; D 9.3.2; D 9.3.3; D 9.3.4). The partners could turn against co-partners for the breach of the undertaken obligations (e.g., for not delivering goods a.o.). (D 17.2.69; D 17.2.65.14). For 
inappropriate management of the financial means of the partnership and their use for personal needs, interest should be paid (D 22.1.1.1). In order to handle mutual obligations the partners were entitled to use slaves belonging to the partnership (D 46.4.8.2; D 45.3.7.1). There was a special regulation in respect of female partners (D 16.1.1 pr.; D 16.1.17.2) and those under the power of the father (patria potestas-lat.) (I 2.9.1; D 14.6.2; D 49.17.18.2; D 45.3.18 pr.), or particular business transactions were arranged - lending of money (D 12.1.16), common building and management of the estate (D 17.2.52.13; D 17.2.39; D 45.1.140.2 ), joint purchasing of the land (D 18.2.1; D 18.2.18), renting of public (state) property (loco publico - lat.) (D 43.9 .1 pr.; $\mathrm{D}$ 43.9.1.2). Issues regarding the solvency of the partners were regulated (D 17.2.63.7; D 17.2.63.6; D 17.2.63.5; D 17.2.67 pr.). In contrast with a standard situation (D 50.16.234.1; D 50.17.95; D 50.16.114) there was an exception regarding the partnership contract - a partner was not entitled to claim more than his co-partner was able to pay (I 4.6.38) without applying forced debt deduction (D 24.3.54; D 42.1.16) - this privilege referred only to the partner - defendant and it could not be transferred to others (D 44.1 .7 pr.), it was not enjoyed by the persons who denied their participation in the partnership or were responsible for malicious action. (D 42.1.22.1; D 17.2.63.7). Admittance of new partners was limited. If somebody was admitted to the Roman partnership he was a partner (had a direct contractual relations) only in regard to the partner who had invited him (D 17.2.19; D 17.2.20; D 50.17.47.1). To become an equal partner to all partners, the approval of everybody was necessary- amendments to the current partnership contract or conclusion of a new contract (D 17.2.21; D 17.2.22; D 17.2.23 pr.; D 17.2.23.1).

9. In case of interaction of the concepts of marriage and the partnership contract, the priority usually was given to the concept of marriage. In particular it referred to claims regarding the dowries of the partners' wives/daughters, those claims, with some exceptions, were satisfied in priority (D 17.2.65.16; D 17.2.66; D 17.2.81). It was common to finance dowry of the partners' daughters from the financial means of the partnership (D 17.2.81). Roman marriage as such was considered as some kind of „life's partnership" - „societas vitae” (lat.), the fact that was correspondingly substantively and procedurally seen in the case of claims brought between the spouses (D 25.2.1; D 24.3.54; D 42.1.52). In case between a husband and a wife a partnership contract for the purposes of the gift was concluded, this contract like any other partnership contract with the purpose to give gift, was to be recognized as invalid (D 24.1.32.24). It must be added that according to the general rule any gift transaction between spouses was recognized as invalid (D 24.1.1).

10. It was not possible to inherit the status of the partner and a place in the Roman partnership contract. If any of partners died, the partnership 
ceased to exist - if not agreed otherwise when establishing it (D 17.2.65.9; D 17.2.52.9; C 6.22.1 pr.). An exception - for the purposes to collect partnership's taxes - it could continue to exist also after the death of the partner (D 17.2.59 pr.; D 17.2.63.8). The heir of the partner was entitled to share in the profit of his predecessor that was supposed to be distributed among the partners after dissolution of the partnership (D 17.2.65.9; D 4.3.20.1; D 17.2.63.8; C 4.37.3), also losses were binding to the heirs. (D 17.2.65.2; D 17.2.63.8; D 17.2.65.9). Even though a heir was not a partner of the partnership, his duty was to improve consequences due to negligence (culpam - lat.) of his predecessor (D 17.2.36) he had to accomplish things his predecessor has started but has not finished, furthermore any bad faith or intentional harm (quibus dolus - lat.) committed by the deceased had to be taken into account (D 17.2.35; D 17.2.40). Discredit (infamia - lat.) of personal nature was not transmitted to the heir - the heir was liable solely for the material debts of the deceased (D 3.2.6.6). The remaining partners together with heirs of the deceased partner could conclude a new contract regarding establishment of a new partnership (D 17.2.37). In relation to mutual interaction of the concept of heritage and those of the partnership contract several situations typical of Roman mode of life were regulated (see D 29.2.42.1; D 45.1.140.2; C 4.37.4; D 17.2.62; D 26.7.47.6; D 32.30.4; D 17.2.63.9; D 28.5.90 (89); D 28.5.8 pr.; D 28.5.8.1; D 40.4.48; D 38.1.36; D 38.2.1.1; D 38.2.1.2; D 38.2.2 pr.; D 34.1.16 pr.; D 34.1.16.3; D 34.3.1 pr.; D 34.3.3.4; D 34.3.3.5; D 34.3.3.3; D 34.3.29; D 34.3.5.1; D 32.11.21; D 35.2.1 pr.; D 35.2.62 pr.; D 28.7.4 pr.; D 10.2.39.3; D 28.5.60. (59.) 1; C 10.14.1). Similar to the case regarding the heir, participation in the partnership contract was not transmitted to the arrogator (ita nec ad adrogatorem - lat.), who through the concept of the arrogation has accepted a partner of the partnership under his power of a father - has conferred to him the status equal to the one of his own child (D 17.2.65.11).

11. It was indicated that it was impossible to establish an eternal partnership (D 17.2.70). The partnership contract could terminate when a partner resigns, upon the death, by losing rights of a citizen and because of general poverty (D 17.2.4.1). According the legal definition (D 17.2.63.10) provided by the jurist Ulpianus (Domitius Ulpianus, ? - 228A.D.), the partnership ceased to exist: if those who have established it ceased to exist (see also: I 3.25.5; D 17.2.59 pr.; D 3.5.20.2; D 17.2.58.2; D 17.2.58.3; I 3.17 pr.; I 3.17.1.; D 15.4 tit.), upon losing the property of the partnership (see also: I 3.25.8; D 17.2.65.1; D 17.2.65.12; I 3.25.7), according to the will of the partners to dissolve it (see also: C 4.37.5; I 3.25.4; D 17.2.65.3; D 17.2.65.3; D 17.2.64; D 10.3.16; D 17.2.17.1), by taking legal actions. The partners terminated the legal existence with the complete or intermediate decrease of legal capacity or upon the death. The property was considered to be lost if nothing was left over from it or its legal status has changed - it ceased to 
exist, was removed from the civil circulation for sacral purposes, has become public - alienated for the benefit of Roman nation - state. The partnership ceased to exist if the parties expressed the will to leave it. (D 17.2.63.10). Due to legal actions the partnership ceased to exist only then when by the agreement of the parties or court ruling its purpose has been changed or legal measures were taken with purpose to dissolve the partnership (D 17.2.65 pr.). The partnership that was established for a certain goal, ceased to exist by reaching this goal. (I 3.25.6; D 17.2.65.10). By ending the partnership contract, joint property rights (communio, also condominium - lat.) regarding the property of such partnership was preserved. In distribution of such property special claim was applied (actio communi dividundo - lat.) (D 17.2.65.13; D 10.3.1) - a universal claim to divide any joint property (D 10.3.2 pr.). Distribution of the property was performed by an appointed arbiter (arbiter - lat.) according to the Roman Civil Procedural rules. (C 3.38.2; C 3.37.3 pr.; C 3.37.3.1; C 9.20.6). Undivided joint property was managed as legally integral combination of undivided share belonging to the parties (D 17.2.83; D 10.3.14.3). It was not possible to force a partner to stay in the partnership, if he did not want that (C 3.37.5; D 10.3.14.4). If there was an agreement not to leave the partnership for some time, the partner who left it prior to the set date and in not favourable economic situation, this partnership withdrawal was valid, but the others were entitled to the compensation (D 17.2.14; D 17.2.65.5; D 17.2.17.2). The partner was not liable for his partnership withdrawal if he could not enjoy the benefits because of which the partnership was established (D 17.2.15), conditions regarding the partnership establishment were not fulfilled or copartners caused to him serious harm (D 17.2.14). By withdrawing the partnership, one could excuse himself with being busy at the state service sometimes this excuse was denied, because a partner could run his business with the help of other person (D 17.2.16 pr.). By withdrawing the partnership a partner exempted others from the liability as far as he was concerned but he was not exempted from the liability regarding co-partners (D 17.2.65.3; D 17.2.65.6). In case profit was gained after this withdrawal, the former partner was not entitled to it, however in case of expenses, the one who had ruined the partnership had to cover them (D 17.2.65.6) - in case the partnership withdrawal was performed with malicious intentions (D 17.2.65.3; I 3.25.4; D 17.2.65.4). Withdrawal could be performed both by the very partner or his representative (D 17.2.65.7). Also withdrawal notice could be given not only to the very partner but also to his appointed representative (procurator - lat.) (D 17.2.65.8). In case a slave was a partner, it was not enough for his owner to give an order for withdrawal - his duty was to inform other co-partners about his slave's withdrawal (D 17.2.18). If a person of unsound mind was a partner, withdrawal rights were transmitted to his trustee (furiosi curatorem - lat.) (C 4.37.7). 
12. An action or a claim deriving from the partneship contract (actio pro socio - lat.) was a procedural mechanism - ,a claim before the court” (actio - lat.), by help of which the partners of the partnership (societa - lat.) could force their co-partners to fulfil undertaken obligations and achieve protection of their violated interests (D 2.14.7.1; D 2.13.9 pr. ). A claim belonged to the category in personam (lat.) (I 4.6.17) - it was brought against the defendants who were personally liable according to the concluded agreement (contract) or because of performed illegal actions. (I 4.6.1; I 4.6.20) A claim was to be reviewed in good faith (bonae fidei - lat.) (I 4.6.28; D 17.2.52.1) - a judge had a discretion (libera potestas - lat.) to interpret legislation and to decide the case by taking into account actual circumstances by observing the principles of justice and honesty (I 4.6.28; I 4.6.30). The partnership intervened in the court proceedings as a separate party (D 17.2.31). From the procedural perspective it was possible to unite connected cases. (D 17.2.52.14). A claim could be brought against actual not figure contracting party (D 17.2.84). The parties were obliged to give security (payment of security deposit) (D 17.2.38 pr.; Gaius, inst 4.14 ). It is known about procedural, in particular about limitation time-limits (30 years, 40 years) (C 7.40.1.1c; C 7.40.1.1d; C 7.40.1.1e). A claim could be brought only in case of the partnership contract (D 17.2.31; D 17.2.32; D 17.2.33; D 17.2.34). As regards an ancillary claim deriving from the partnership contract the partners could bring also other claims resulting from actual circumstances of the case in respect of the distribution of the joint property, (D 17.2.34; D 10.3.1; D 17.2.43; D 17.2.38.1), a theft (D 17.2.45; D 17.2.46; D 17.2.47 pr.), damaging the partnership's property - according to so called Aquilia law (Lex Aquilia) (D 17.2.47.1; D 17.2.49; D 17.2.48; D 17.2.50), regarding kidnapping, hiding and facilitating the escape of slaves of the partnership according to Lex Fabia (D 17.2.51.1). However a claim regarding a theft was applied only then if fraud or malicious intention of the partner's action was established - if this was not the case, there was no liability for a claim regarding a theft (D 17.2.51 pr.) (Apsîtis; Joksts 2013). In case penalties had already been applied to a partner in relation to a separate agreement, right to bring claim deriving from a partnership contract was limited. (D 17.2.71 pr.; D 17.2.41; D 17.2.42). If any debtor promised to the one of two partners equally interested creditors to arrive to court and to pay penalty in case he does not come to court hearing, and the second partner precluded the debtor from keeping his promise, penalty was not to be paid - so that one partner is not benefiting from fraud (dolus - lat.) of another one (D 2.11.5 pr.; D 2.11.5.1). A claim deriving from a partnership contract could be brought against the person who has taken an oath (fecisse iuraverit - lat.) that he/she has concluded a partnership agreement; this oath related also to other claims stemming from this claim (D 12.2.13.4; D 12.2.28.4). Furthermore the Roman jurists examine several particular situations with the aim to determine whether the 
corresponding contract could be regarded as the partnership contract and falls within jurisdiction of the claim actio pro socio (lat.) (D 17.2.44 ; D 19.5.13 pr.; D 17.2.52 pr.; D 17.2.52.7; D 19.5.13.1; D 17.2.65.15). The partners were entitled to agree that dispute is reviewed by the arbitrator appointed by them (D 4.8.34 pr.; D 4.8.34.1). Being recognized to be liable for a claim deriving from a partnership contract included also additional liability for breaching ethical canons - so called concept of „being discredited”. (infamia - lat) (C 2.11.22; D 3.2.1; D.3.2.6.4; D 3.2.6.1; D 3.2.13.5; D 3.2.6.7; D 3.2.7) (Apsītis ; Joksts 2013) .

13. Roman corporative bodies - associations (universitatis - lat.), colleguims and corporations (collegiis et corporibus - lat.) were artificial subjects of law which existed independently from the existence of a man, they had rights to their autonomous property and their capacity to act was fulfilled with the help of their representatives - natural persons. (I 2.1.6; D 3.4.1.1). Before the court a corporative body could be both a claimant and a defendant enjoying the same procedural rights like a natural person. Right to judicial protection was carried out through representatives (D 3.4.7 pr.; D 3.4.9). Liabilities of the corporative bodies were separated from the private liabilities of their partners - a debt in favour of an association was not a debt in favour of its partners the same as the debt of an association was not a debt of the partners (D 3.4.7.1). Three partners were necessary to establish a corporative body, afterwards it maintained its status of autonomous legal subject despite the number of the partners. An association continued to exist also with one remaining partner. (D 50.16.85; D 3.4.7.2). The establishment of the corporative bodies was strictly regulated, the approval from the state was needed (D 3.4.1 pr.; D 47.22.3.2; D 47.22.1pr.; D 47.22.1.1; D 47.22.4; D 47.22.1.2); the state acted severely in respect of illegally established corporative bodies (D 47.22.2; D 47.22.3 pr.; D 47.22.3.1). Partners of the corporative bodies had rights to appoint authorized representatives or heads (actorem sive syndicum - lat.) who acted on the behalf of the whole body not on the behalf of separate partners (D 3.4.1.1; D 3.4.2). An authorized representative (actor - lat.) could be appointed also only for fulfilment of concrete tasks ( D 3.4.10). Alongside with the authorized representatives (actor - lat.) there were ordinary agents (procurator - lat.) (D 3.4.6.3). If there was nobody to represent the body, the state could take over in its possession body's property, and if after issuing a warning, its partners did not perform any defence measures, the state could sell the property (D 3.4.1.2) If a foreigner appeared to defend an association (universitatem - lat.) he was allowed to do it, similar to the cases of defence of natural persons (D 3.4.1.3). If the corporative bodies (civitates - lat.) were not defended by the agents and there was no joint property to be obtained in possession, imposed payments were supposed to be made in favour of them who have initiated court proceedings regarding the recovery of the debts from corporation's debtors (D 3.4.8) To initiate court 
proceedings - to represent the corporative body before court could only that one who was authorized by the law to do so, but in cases of no such law he was authorized by voting if the rules on counting the votes and request for $2 / 3$ of quorum were satisfied- the decision should have been taken by being present at least two thirds of all persons having the right to vote (D 3.4.3; D 3.4.4; D 3.4.5.; D 3.4.5.; D 3.4.6 pr.). The procedure to appoint the representative could be delegated to the corresponding authorised representation institutions (D 3.4.6.1). A representative for the court proceedings was appointed only for each particular case - it was not common to give universal overall authorisation An exception - representatives of corporative bodies authorized by the law - an official („heads" - syndic(lat.)) who had power to realize the representation in any case without a separate authorisation (D 3.4.6.1). A representative appointed for court proceedings acted only within the time-limits of the given authorisation - an institution which has authorized him, could withdraw this authorisation (D 3.4.6.2). If the representative was authorized to bring a claim, his duty was also to defend it in the court. A separate authorisation was needed in order to bring a claim regarding the execution of the judgement or to receive payment or promise to pay (D 3.4.6.3)

\subsection{Influence of the Roman legal ideas on the modern substantive and procedural rules of the Republic of Latvia}

Theses regarding the research question 2 :

„Whether the impact of legal ideas developed by the Romans can be observed in substantive and procedural rules of different fields of law of the Republic of Latvia?" :

14. Within the reception of provisions of law and the development of the history the principles developed by the ancient Romans have been incorporated also in the modern legislation of the Republic of Latvia which contains following Roman concepts: in respect of limiting/not limiting the duration of the activity of a partnership contract and establishing the time when contract enters into force (D 17.2.1.pr. vs CL 2242; CL 1548; CL 1551; CL 1579; KoL 100. 1)), necessity for the party of the legal transaction to express free will and invalidity of a transaction concluded in the result of mistake (D 44.7 .57 vs CL 1440; CL 1445; CL 1447; CL 1448; CL 1450 a.o.), a certain form of a partnership contract (a legal transaction) (D 17.2.4 pr.; D 44.7.2.1; D 44.7.2.2 vs CL 1428; CL 1430; CL 1473; see. CL 2241 - CL 2280; see KoL 77KoL 133) and advantages of the written form (C 8.17.11 pr. vs CL 1483.4); CL 1431), right to include ancillary rules, including conditions in every contract (C 4.37.6 vs CL 1548; CL 1549; CL 1551) and also introducing the provisions and limitation of the duration of the partnership contract with a temporary goal (D 17.2.5. pr. vs CL 2242). Under the Civil Law it is allowed to 
contribute the work of the partner of the partnership (D 17.2.5.1; C 4.37.1 vs CL 2243), however under the Commercial Law contribution in the form of work in the equity capital of the modern SIA and AS is forbidden (KoL 151(1); KoL 153(2)). According to the Civil Law - an illicit or indecent action, the purpose of which is contrary to religion, laws or moral principles, or which is intended to circumvent the law, may not be the subject-matter of a lawful transaction (D 17.2.57; D 18.1.35.2; D 46.1.70.5; D 27.3.1.14; D 48.10.1 pr. vs CL 1415). No contract which encourages anything illegal, immoral or dishonest shall be binding (D 17.2.57; D 18.1.35.2; D 46.1.70.5; D 27.3.1.14; D 48.10.1 pr. vs CL 1592). The Civil Law partly departs from the Roman principle in respect of the fact that the partnership contract concluded by fraud is void - transaction is not void, it can be contested. (D 17.2.3.3; D 4.4.16.1 vs CL 1461). The Commercial Law contains the Roman concept to attract an expert to evaluate impact of the partner in the partnership - regarding property contributions in the equity capital of SIA and AS. (D 17.2.76; D 17.2.77; D 17.2.78; D 17.2.80 vs KoL 154 (1),(2)). Latvian Civil Law reflects modified Roman legal traditions - unless otherwise determined by the partnership contract, fungible and consumable property shall be regarded as transferred to the joint ownership of the partners, but non-fungible and inconsumable property - as transferred for use ( D 19.5.13.1 vs CL 2244) (as regards the equity capitals of SIA and AS the contributed property shall become the property of the company (D 19.5.13.1 vs KoL 151(4))). The Civil Law incorporates the Roman idea regarding limiting division of the partnership's property belonging to the partner - the partner may not require a division while he or she is a partner of the partnership (D 17.2.16.1; D 17.2.17 pr. vs CL 2245).

15. The Civil Law contains Roman principles in respect of an action with the profit and the losses of the partnership (each partner shall share with other partners such profit that are due, pursuant to its character, to the partners of a partnership (D 22.1.38.9; D 17.2.52.5; D 17.2.52. CL 2246) and losses by modifying the Roman approach, it is allowed to determine in what proportions the partners shall share in profits and losses, if a contract does not contain rule on that and all contributions have been paid/ evaluated in terms of money, the profits/ losses shall be divided among the partners in proportion to the amount of the contribution of each partner, but if contributions have not been paid/evaluated in terms of money - in equal shares (C 4.37.3; I 3.25.1; I 3.25.2; D 17.2.30 vs CL 2248) (according to the Commercial Law the amount of the profit of a partner of PS/KS (KoL 88 (2)) or shareholder of SIA/AS (KoL 161(2)) depends on the proportion of their contribution), establishing conditions regarding the solely distribution of profits or losses, conditions apply both to profits and to losses, (I 3.25.3 vs CL 2248), it can be agreed that a partner who participates in the partnership only in the terms of an individual work, shall share in profit but not in losses (I 3.25.2; D 17.2.29.1 vs 
CL 2247), it is not allowed to establish „Lion” type partnership (17.2.29.2 vs CL 2247). Similar to the Romans, the Commercial Law provides that PS/KS partner has the duty to pay interest if he/she has failed to pay his or her money contribution within a specified period of time, or has not transferred money collected or has taken money from the cashier's office of the partnership without authorisation, (D 17.2.60 pr.; D 22.1.1.1 vs KoL 81 (1)), shareholder/ stockholder of SIA/AS has duty to return the amount acquired without justification (D 17.2.60 pr. vs KoL 162 (1)), also partners of a modern PS and KS have rights to be reimbursed for losses incurred when handling partnership matters (D 17.2.52.4 vs KoL 80 (1)). Regarding PS or KS the Commercial Law contains the concept that a partner have rights to be reimbursed for damages incurred when handling partnership matters and that partnership has an obligation also to pay interest at the legal rate, which shall be calculated from the time the expenditures were incurred (D 17.2.38.1; D 17.2.67 pr.; D 17.2.67.2 vs KoL 80 (1),(2)).

16. Roman legal traditions are reflected in the provisions of the Commercial Law on unlimited liability of PS partners (D 17.2.63 pr. vs KoL 94 (1),(2)) and KS general partners in respect of the obligations of the partnership (D 17.2.63 pr. vs KoL 118 (1),(2)), the right of all partners of PS to represent the partnership, unless they have been excluded from representation (D 2.14.27 pr.; D 14.1.5.2; D 2.14.25 pr.; D 2.14.24 vs KoL 91 (1)), usefulness of the joint representation and rights to determine such joint representation (D 14.1.1.14 vs KoL 91 (2); KoL 223 (1); KoL 303 (1); KoL 35 (2) ), in the Civil Law regarding rights to agree to assign the handling of partnership matters to one/several partners or to the third persons (D 14.1.4.1 vs CL 2253 ) and in the provision that transactions entered into by the agents within the limits of their authority shall be binding without limitation and solidarily, except in cases where otherwise agreed with third persons (D 14.1.4.1; D 14.1.6.1; D 14.3.13.2; D 14.3.14 vs CL 2257). Regarding limiting the authorisation of the agents, the Civil Law under influence of the Roman traditions, allow to restrict such authorisation (D 14.1.1.7; D 14.1.1.12 vs CL 2257 ; CL 2254 ; CL 2301), however the Commercial Law as a special law does not accept authorisation's restrictions regarding the third persons. (KoL 92 (2); KoL 223 (3); KoL 303 (3); KoL 36 (1); KoL 34.(2); KoL 92 (3)1),2),3) ). According to the Civil Law (D 12.1.16 vs CL 2252) and to the Commercial Law (D 12.1.16 vs KoL 87 (1),(2))), to take a decision the consent of all the partners of the partnership or majority of votes shall be necessary. The impact of the Roman traditions can be observed in the provisions of the Commercial Law on the right of PS partner/ KS general partner to refuse to satisfy a claim by a creditor while the PS/KS has a right to contest the transaction which is the basis of the obligation or the creditor may satisfy the claim by an off-set (D 17.2.27 vs KoL 95 (2),1),2)), and on the basis of an adjudication which has come into legal effect in a matter, in which the 
defendant is the partnership, collection may not be made against the property of PS partner/KS general partner (D 17.2.27 vs KoL 95 (3)). The Roman traditions are reflected in the provisions of the Civil Law that regarding a contract entered into without authorisation by the other partners, liable shall be only such partners who have entered into the contract (D 3.5.7.3 vs CL 2258) (Commercial Law contains modification of Roman tradition - a partnership contract may specify that all or several partners of PS are entitled to represent the partnership only jointly (D 3.5.7.3 vs KoL 91(1),(2)) a.o. - see.: KoL 92(1); KoL 93; KoL 91 (4) ; KoL 92 (2)), where a partner enters into a transaction with a third person in his or her own name, he or she alone shall be liable to such third person (D 45.3.28.3 vs CL 2259), a joint debtor may propose as setoff only his or her own counterclaims against the creditor unless the joint debtors are in a partnership relationship (D 45.2.10 vs CL 1684).

17. In contrast with the Roman approach admittance of a new partner to already existing PS or KS is possible (KoL 96(1)), however similar to the Romans, approval of all involved parties is necessary for admitting the new partner (D 17.2.21; D 17.2.22; D 17.2.23 pr.; D 17.2.23.1 vs KoL 77(1); KoL 118 (1); CL 1427; CL 1511). The Civil Law continues Roman tradition a partnership is terminated upon the death of a partner (D 17.2.52.9 vs CL 2262.4)), if a partnership contract stipulates that the partnership shall continue the deceased partner shall be regarded as withdrawn one. (D 17.2.65.9 vs CL 2262.4) ; CL 2268). If a partnership terminates upon the death of a partner, the heirs of the deceased person shall immediately notify other partners about the death and continue the estate-leaver's affairs pending the provision of further instructions by the partnership or the liquidator (D 17.2.40 vs CL 2266), other partners shall also continue their activity (D 3.5.20.2 vs CL 2266). According to the Civil Law a duty to compensate for losses shall pass to the heirs of the person who has caused these losses, unless otherwise provided for by the law. (D 17.2.65.2; D 17.2.63.8; D 17.2.65.9 vs CL 1783). The Commercial Law reflects modified impact of the Roman principles - in the case of the death of a partner of PS/KS, his or her heir has the right to become a partner of the partnership, if this is specified in the partnership contract or all partners of the partnership agree to it. (D 17.2.65.9 vs KoL 104 (1)). If a heir does not wish to/cannot become a partner of the partnership, or the other partners disagree, the heir has a right to receive that what in conformity with his or her part of the estate would have been due to the deceased partner of the partnership at the time of the opening of the succession. (D 17.2.65.9; D 17.2.63.8; C 4.37.3 vs KoL 104 (4)). Similar to Roman times, according to the Civil Law a partnership shall cease if all the partners agree thereto (D 17.2.65.3 vs CL 2262.1)) or a partner gives notice with respect to the partnership contract - in case this contract does not provide ongoing existence of the partnership after such notice (I 3.25.4 vs CL 2262.4) ; CL 2268). A provision of a contract whereby the right to give notice is not allowed shall 
not be valid (D 10.3.14.4 vs CL 2264). The Commercial Law provides right of the partners of PS/KS to withdraw from the partnership, providing a notice of termination (C 3.37.5 vs KoL 99 (1)). According to the Civil Law it is forbidden to give notice in bad faith - otherwise such partner shall be held liable for losses and the partner shall not share in the profit the partnership acquired after such notice (D 17.2.14; D 17.2.65.5; D 17.2.17.2; D 17.2.65.3; D 17.2.65.6; I 3.25.4; D 17.2.65.4 vs CL 2264). The Civil Law provides the right of a partner for good cause, to request termination of the partnership (D 17.2.15; D 17.2.14 vs CL 2263). If a partnership terminates otherwise than through giving notice, the right of management of a partner shall be regarded as still subsisting until the time when he or she comes to know of the termination, or when he or she should have known of such termination. (D 17.2.17.1 vs CL 2266). The Commercial Law provides that a PS/KS terminates by the decision of the partners of the partnership (D 17.2.65.3 vs KoL 97 (1) 2)). The Civil Law provides that a partnership terminates if concursus proceedings are initiated or administration is established with respect to partner's property (I 3.25.8; D 17.2.65.1 vs CL 2262.4)), as well as the right of a creditor, in executing a court judgment, to give notice on the behalf of a partner, distrain the contribution and perform collection (D 17.2.65.1 vs CL 2265). However in comparison with the Romans it is allowed to continue partnership contract if so provided in this contract (I 3.25.8 vs CL 2268). The Commercial Law provides - the declaration of the partner of the partnership as insolvent is the ground for withdrawal - if not provided otherwise in the contract (KoL 97 (2) 2)). The Civil Law provides the right of the state authority (,government") to prohibit the further existence of the partnership (D 17.2.65.12; I 3.25.7 vs CL 2262.5)), The Commercial Law provides termination by the court ruling (D 17.2.65 pr. vs KoL 97 (1) 4); KoL 98 (1)). The Civil Law provides that a partnership shall be terminated if the goal set for the partnership is achieved (I 3.25.6 vs CL 2262..3)),.The Civil Law also provides that when liquidating the partnership rules on distribution of joint property shall be applied (D 17.2.65.13; D 10.3.1 vs CL 2275). Joint owners have the right to require the division of the common property (D 10.3.2 pr. vs CL 1074.) and to alienate or pledge the share of the common property belonging to them (D 10.3.14.3 vs CL 1072).

18. The Civil Law has adopted the Roman conception about the gradation and levels of civil liability - taking into account the fact whether an action was committed with evil intent, or only due to negligence (D 50.17.23; D 13.6.5.2; D 17.2.52.2; D 17.2.52.11 vs CL 1640), by defining concepts of evil intent (dolo - lat.) (D 47.8.2.8; D 17.2.68.1 vs CL 1641) and negligence (culpa - lat.) (CL 1644.p.) - gross (culpa lata - lat.) (D 50.16.213.2; D 50.16.223 pr. vs CL 1645) and ordinary (culpa levis - lat.) (D 7.1 .65 pr.; I 3.25.9 vs CL 1646) Limit of liability among the partners goes to an ordinary negligence (culpa levis - lat.) (D 7.1.65 pr.; D 17.2.72; I 3.25.9 vs CL 2250.), 
excluding liability for an accidental event (casus - lat.) and force majeure (vis maior - lat.) (D 17.2.52.3; D 50.17.23; D 19.2.25.6; D 44.7.1.4 vs CL 1773; CL 1774) (with an exception to e.g. hotel keepers a.o. - they are responsible also in case of an accidental event (casus - lat.) (D 4.9.6.1 vs CL 1998)). Under the influence of Roman traditions the Civil Law provides for mutual off-set in the situation of bilateral negligence (D 16.2.10 pr.; D 16.2.10 1. vs CL 1650) and forbids mutual claims in the event of fraud or evil intention (D 16.2.10 pr.; D 16.2.10 1. vs CL 1462). A contract whereby someone has negotiated something for oneself for refraining from an illegal action or merely for performing one's duty shall not be binding. (D 50.17.23 vs CL 1571). It is possible to declared invalid transaction concluded by fraud ( D 4.4.7.1; D 4.4.16.1; D 4.4.6 vs CL 1461) - unlike the Romans, such transactions are not automatically regarded as void. The Civil Law contains negative attitude characteristic to Roman tradition in respect of the obligations arising from gambling - they neither enjoy protection by law (D 17.2.59.1 vs CL 2283), nor judicial protection (D 17.2.59.1 vs CL 2284).

19. The Civil Law has inherited the Roman concepts regarding the fact that accidental loss (where caused by a chance event or force majeure) (D 19.2.25.6; D 44.7.1.4 vs CL 1773)) shall not be compensated (D 19.2.25.6 vs CL 1774) that each of the joint debtors may be forced to perform the whole obligation, and their performance shall release the others (D 45.2.2 vs CL 1682) that it depends on a debtor 's discretion as to which of several joint creditors will perform an obligation (D 45.2.2 vs CL 1681), that the one who has instructed to perform an illicit act shall be liable for it, notwithstanding that the acts of such person exceed the limits of the instructions (D 9.4.1 pr.; D 9.4.2 pr. vs CL 1781), that the one who fails to exercise due care in choosing servants a.o. employees, shall be liable for losses they have caused (D 39.4.1 pr .; D 39.4.3 pr. vs CL 1782), that the bailee who undertakes to keep the property without compensation, shall be liable only for malicious intent (dolo (lat.)) or gross negligence (culpa lata (lat.)) (D 16.3.1.6 vs CL 1972) and that it is possible voluntarily to increase limits of liability to an accidental event (casus (lat.) (CL 1974.1)) (for Romans this limit was lower - to negligence - culpa (lat.) (D 16.3.1.6 vs CL 1974.1))). According to the Roman legal tradition the concept of dowry is regulated in the Civil Law (D 23.3 tit.; D 23.4 tit.; D 23.5 tit.; D 24.3 tit.; D 25.1 tit.; C 5.12 tit.; C 5.13 tit.; C 5.14 tit.; C 5.15 tit.; C 5.18 tit.; C 5.19 tit.; C 5.20 tit.; C 5.22 tit.; C 5.23 tit.; C 7.74 tit; D 17.2.81 vs CL 111-113). as well as right of spouses to bring claims against each other (D 25.2.1; D 24.3.54; D 42.1.52 vs CL 85). Under the influence of Roman principles the Civil Law provides that all obligations, other than exclusively personal ones, shall devolve to the heir (D 3.2.6.6 vs CL 705). The Civil Law provides for guardianship established over the persons lacking capacity to act due to mental illness or mental deficiency. (C 4.37.7 vs CL 217. 1); CL 217. $1^{1}$ ); CL 360 ; CL 364. ${ }^{2}$ ). In the Civil Law in a transformed form exist 
traditions of the concept - under power of father (patria potestas - lat.) - child is under ,the custody" of his or her parents (until 01.01.2003. - ,under power of parents") (D 17.2.58.2 vs CL 177), parents are not liable for obligations entered into, without the consent of their parents, by minors who are in the custody of their parents, unless they themselves have not gained some benefit therefrom (D 17.2.58.2 vs CL 197). According to the Civil Law lawful transactions can be made also through substitutes (D 17.2.16 pr. vs CL 1410).

20. Modern Latvian Civil Law also provides that a partner may bring an action, in his or her own name, against any co-partner with respect to performance of the duties assumed under the partnership contract (D 2.14.7.1; D 2.13.9 pr. vs CL 2250). Under the provisions of the Commercial Law PS/KS can be both a claimant and a defendant before the court, collection on the property of a partnership may be commenced only after a court ruling in a matter in which the defendant is the partnership. (D 17.2.31 vs KoL 90 (1) - (2)). Modern Latvian legislation contains Roman conception about procedural time-limits (C 7.40.1.1c ; C 7.40.1.1d; C 7.40.1.1e vs CPL 46 (1); KoL 116; KoL 117), tradition to unite related proceedings for the purpose of usefulness (D 17.2.52.14 vs CPL 134 (1) - (2)), tradition to define in law the courts action regarding applying of legislation (I 4.6.28; I $4.6 .30 \mathrm{vs}$ CPL 5 (1) - (5) ; CPL 8 (1)), the right to bring a counterclaim (D 3.2.6.7 vs CPL $136(1)-(2),(4))$, the concept of settlement is incorporated (D 3.2.7 vs CL 1881; CL 1885 ; CPL 226 (3) ; CPL 226 (1) - (2)), the Roman tradition to set the rules regarding imposing penalties is over taken - as a special concept of contractual penalties (D 17.2.71 pr.; D 17.2.41; D 17.2.42 vs CL 1716; CL 1717; CL 1718). The idea of the securing claims also has become an element of the modern procedural law - though the very means of securing have become more modern (D 17.2.38 pr.; Gaius, inst 4.14 vs CPL. 137 (1); CPL 139 (1); CPL 138). Nowadays in the most cases the contracting parties are entitled to agree on court of arbitration. Live is also Roman idea about restricting right to bring an action in general court if parties have agreed to transfer the dispute to arbitration court (D 4.8.34 pr.; D 4.8.34.1 vs CPL 23(1); CPL 132 (1) 3); CPL 223 6)). Arbitration proceedings are confidential parallels with the Roman tradition - a mechanism to exclude possible publicity - „discredit” (D 3.2.13.5 vs CPL 512 (1) - (2)). The principle of juridical ethics has derived from the Roman legal tradition - nobody could be recognized to be guilty before he/she is sentenced and the court judgement has not entered into lawful effect - so called ,presumption of innocence”. Procedural legislation has accepted Roman tradition to use system of several court instances (D 3.2.6.1 vs KPL 19 (1); KPL 554 (1); KPL 577 (1); KPL 632 (1) - (2); CPL 203 (1) ; CPL 434 (1) - (2) ; CPL 477). We can be thankful to the Romans for present axiom in criminal law regarding the meaning of the subjective side of the crime in its qualification. (D 17.2.51 pr.) - ,...quia furtum sine affectu furandi non commitur"(lat.) - ,...because there is no theft without an intention 
to steal". (I 4.1.7) (Apsītis; Joksts 2013). Parallels to the Roman constructions can be found in the modern concept of right of a victim to be compensated for harm caused because of a crime (D 17.2.45; D 17.2.46; D 17.2.47 pr.; D 17.2.47.1; D 17.2.49; D 17.2.48; D 17.2.50; D 17.2.51.1 vs KPL 350 (1) - (3); CPL 7 (1) - (2)). In relation to the Roman conception of „discredit”, the idea of additional sanctions has been transformed - possibility to restrict specific rights, e.g. provisions of the Commercial Law regarding restriction on commercial activity for a natural person within the scope of criminal or administrative proceedings (C 2.11.22; D 3.2.1 vs KoL 4 (4)).

21. Legal structure of modern Latvian capital companies (SIA, AS) and associations are based on the Roman principles - they as legal entities with their property separated from the private property of their shareholders (stockholders, partners) conclude legal transactions through their lawful representatives - members of the board (I 2.1.6; D 3.4.1.1 vs KoL 135 (1); BNL 2 (1); BNL 3.; KoL 151 (4); KoL 163 (4); KoL 182 (1),(2); KoL 301 (3); KoL 323; KoL 328; KoL 372 (1); BNL 7 (1); CL 1410; KoL 221(1); KoL 301 (1)).; BNL 42 (1),(2),(3); KoL 221 (2),(3); KoL 304 (1),(2)). The capital company continues to exist as the legal entity also after changes made in the structure of shareholders/stockholders despite the number of remaining shareholders/stockholders (D 50.16.85; D 3.4.7.2 vs $\mathrm{KoL} 140$ (2); KoL 188 (1); KoL 238 (1); KoL 135 (1)). In relation to the Roman association we can speak about the beginning of the limited liability concept when capital company or association is not liable for shareholders' obligations and shareholders are not liable for obligations of the capital company or association (D 3.4.7.1 vs KoL 137 (3); KoL 137 (2); BNL 4 (2); KoL 137 (1); BNL 4 (1)). Also Latvian procedural legislation recognizes equal civil-procedural legal capacity and capacity to act of legal entities (capital companies (SIA, AS), associations a.o.) and of natural persons. In the court proceeding the legal entities are represented by their officials or other authorized persons. (D 3.4 .7 pr.; D 3.4.9; D 3.4.6.1 vs CPL 71 (1),(2); CPL 72 (1); CPL 82 (2); KoL 135 (1); BNL 3) Person represented may at any time withdraw the authorisation given to its representative. (D 3.4.6.2 vs CPL 87 (1)). A representative has the right to perform, on behalf of the person represented, all procedural actions, except those that require special authorisation. Similar to the Romans special authorisation inter alia is necessary for submitting execution documents for recovery, receiving property or money adjudged (D 3.4.6.3 vs CPL 86 (1); CPL 86 (2)). As regards the legitimacy of the decision making bodies (meeting of stockholders, partners and shareholders) of modern Latvian associations and capital companies the Roman concept about quorum is applied. (D 3.4.3; D 3.4.4; D 3.4.5.; D 3.4.5.; D 3.4.6 pr. vs BNL 37 (1); KoL 212 (1); KoL 275). The Roman principles form the basis of the operation of boards of the capital companies (SIA and AS) (D 3.4.1.1; D 3.4.2 vs KoL 221 (1); KoL 224 (1); KoL 223 (1); KoL 223 (3); KoL 
301.p.(1),(2),(3); KoL 303 (1); KoL 303 (3) ), it may be determined in the articles of modern association that another body shall be formed in addition to the executive board for the performance of certain activities (D 3.4.10 vs BNL 48). Also the legislators of the modern democratic countries are familiar with the right of the state power within the context of law and according to the order provided by the law to act against legal entities endangering legality (D 47.22.2; D 47.22.3 pr.; D 47.22.3.1 vs BNL 57(1)1); KL 70. ${ }^{1}$ KL 70. ${ }^{2}$ (1)1); $\left.\mathrm{KL} \mathrm{70.}{ }^{3}(1) ; \mathrm{KL} 70 .^{3}(3) ; \mathrm{KL} 70 .^{3}(2)\right)$. Although the approach that is facilitating not restricting freedom of association and development of commercial activities is characteristic to the modern Western, including also Latvian legal culture , at the same time the necessity to regulate such activities by the law is recognized, as well as it is recognized to apply particular restrictions on individual and public interest - e.g. regulation on principles/order of operation, the request to register, licensing, specific prohibitions a.o. Accordingly it is necessary to point to the implicit impact of Roman legal culture (D 3.4.1 pr.; D 47.22.3.2; D 47.22.1pr. ; D 47.22.1.1; D 47.22.4; D 47.22.1.2 vs BNL 1(1); KoL 134(2); KoL 1(1),(2),(3); BNL 1(2); KoL 3; BNL 3; KoL 1 (1); KoL 6.; KoL 4.; KoL $4^{1} ;$ KoL $\left.4^{2}\right)$. 


\section{CONLUSION}

\section{In the light of the above mentioned submissions, the following summary of conclusions can be done:}

As regards the research question 1 :

1. The economic needs of the partnership of Ancient Rome determined the necessity, but the level of the economic development contained the corresponding preconditions for establishing rather complicated and detailed rules on the consolidation of the economic resources/capital.

2. References in respect of the order of the consolidation of the resources/capital are found in the paragraphs 148-154 of Book 3 (Gaius, inst. 3.148. - Gaius, inst. 3.154.). of the Institutes of Roman Law by Gaius (Institutiones - lat.) who was the Roman jurist (Gaius, acted from 130 A.D. 180 A.D.). However, the main source of law regarding the ancient Roman rules on the consolidation of the capital is so called Code of Justinian or Corpus Iuris Civilis. Codification part Codex Iustinianus book 4, title 37 Pro socio (C 4.37.0.), part Digesta seu Pandectae book 3, title 4 Quod cuiuscumque universitatis nomine vel contra eam agatur (D 3.4.0.), book 17, title 2 Pro socio (D 17.2.0), book 47, title 22 De collegiis et corporibus (D 47.22.0.) and part Institutiones sive elementa book 3, title 25 De societate (I 3.25.) regulated issues regarding the consolidation of the resources in the possession of the persons in order to achieve economic aims. Here can be found $50 \%$ of rules regarding the consolidation of economic resources and the order of collective management. The remaining $50 \%$ are scattered in the very text of code in the form of separate text fragments.

3. Two organisational legal forms of the consolidation of the resources/capital can be distinguished:

i) Roman partnership or partnership contract (societa - lat.),

ii) Roman corporative bodies (,legal entities”) associations (universitatis - lat.), collegiums and corporations (collegiis et corporibus - lat.).

4. Reglamentation of the general principles of the Roman partnership or partnership contract (societa - lat.) includes the conditions regarding the time-limits of the partnership's activity and time-limits within which the partnership contract entered into force, the partnership contract as an mandatory precondition for the existence of the partnership, legal status of the contract, necessity to depict the true will of the contracting parties, prevention of fraud (dolo malo - lat.) and compliance with the principle of good faith (bona fides lat.), provisions on the essential terms of the contract, their form, inclusion of conditions, goals, tasks and kinds of the partnership activity, contribution in the form of work for the benefit of the partnership, situation of the female contracting parties, restrictions and prohibitions in respect of the separate kinds 
of the partnership contracts, aims and intentions for concluding the contracts, provisions of shares of each partner and principles of sharing impact among the partners.

5. The partners of the Roman partnership (societa - lat.) did not lose ownership regarding the contributed property - they became co-owners in respect of the joint fund of the partnership. The partners were able to force their co-partners to invest due things in the partnership. If the aim of the partnership was to sell the consolidated property, the partnership dissolved in case part of this property was lost; if the aim was common management of the property the contract was still valid. In case property contributed by the partner was lost after the moment of investment in the partnership, losses were incurred jointly to all partners, if before - only to unlucky partner. One could not claim from the partnership what was lost due to gambling or due to breach of the marriage, but it was possible to regain that property that was lost because of the malicious intention (dolo - lat.) of other partners. Investments of an illegally obtained property were forbidden, however, if such a property was added to the common fund of the partnership, it was presumed, that it has become part of the joint property and should be considered as the common gain (commune erit lucrum - lat.) of the partners - the investor could remove it only in the case if an action against him was brought regarding returning the misappropriated property - one should return illegally possessed property or such property and penalties. If the co-partners were not aware of the illegal investment, the guilty one was liable on his own, if they were aware - they also had to pay the penalty. If under the partnership contract all the property belonging to the parties should have been invested, the partners were co-owners of the whole property. The debts of the parties remained, but the right to claim against separate debtors of the partners were transmitted to the partnership. Heritages, legates, gifts and other future properties were obtained jointly. The partner preserved his right to indicate his heirs in the testament. The partnership was liable to its partner for damages and harm done to him, it had to repay to him penalties imposed on him, however only in the case when the partner was sentenced without reason. As regards the partnership contract without a rule to invest the all property private debts of the partners did not refer to the partnership and were not binding to it unless they did not derived from the economic activity of the partnership. The partnership had no rights in respect of heritages, legates and gifts meant for its partners.

6. If the principles of the division of the profit and the losses were not stipulated, profit was divided and losses were covered on equal ground for all the partners, in case such provisions on division were stipulated in the contract, they should have been observed. In case provisions regarding share in profit or the part of losses to be covered by each partner were stipulated, it was supposed that the amount of the latter is the same as the amount of the former. Separate partners could be exempted from covering the losses - in case the value of the 
services provided by him corresponded to the part of losses he was exempted from. It was possible to stipulate in the contract different provisions in respect of each partner and the amount of the profit he is entitled to and the amount of losses he is supposed to cover, by observing the principle of proportional division of profit and losses among them. It was not allowed to establish the partnership in which one of the parties was covering only losses without participating in profit (Leonine (lat.) - "Lions"). The partners were entitled to compensation for expenses covered for the benefit of the partnership. The sources speak, e.g., about the reimbursement of reasonable travelling expenses, expenses for tiding out the stream (rivum-lat.) that is common property of the partners a.o expenses. Together with reimbursement of expenses the partners were entitled to collect interest both for investing their money (the same \% rate as in the case of lending money) and borrowed money. Provisions in respect of the medical expenses were determined - e.g. expenses regarding treating an injury got when trying to prevent attempt of the escape of the partnership's slaves, payment to the doctors after being caught by robbers.

\section{As regards legal status, representation and liability for obligations} of the Roman partnership, emphasized should be Digesta book 46, title 1 in which it is indicated that the partnership, similar to mass of succession or municipality are able to act legally in the same way like natural persons. The sources also say that the partnership can have a leader (magister - lat.), who is entitled to undertake obligations on the behalf of it and those obligations are binding to the partnership's business partners (D 2.14.14). However, the partnership contract (societa - lat.) cannot be regarded as a valuable corporative body - the partners were not only responsible for its liabilities with all their property, but this was also a fully joint liability - creditors of the partnership were entitled to bring an action not against the partnership as a corporative body but against each of the partners - usually not proportionally to his share in the partnership but for the total debt of the partnership. At the same time it is indicated that the debts obtained during the existence of the partnership, should be covered from the common fund of the partnership and the partner is entitled to claim from his co-partners his part. To undertake obligations on the behalf of the partnership could both the very partners and representatives appointed by them - e.g. a captain of a ship (magister navis lat.), commercial agent, manager of a commercial or industrial company (institor - lat.) and the leader (magister - lat.). The representatives could be chosen among the partners as well as persons not being partners. They could be both free persons and slaves belonging to its partners or third parties.

8. The principle of justice should have been observed in the mutual relations among the partners of the Roman partnership. „Good faith” (bona fides - lat.) was essential part of the claim deriving from the partnership contract, the case before court was heard by taking into account the actual 
circumstances, eliminating any fraud and unjust action. A partner was liable for the losses his co-partners would suffer due to his neglect (neglegentia eius - lat.) If the partners were blamed for neglect of the same level and value (parem neglegentiam - lat.), off-set was applied in respect of claims among them. The partners were liable both for intentional damage and for negligence. This provision was valid if the parties had not agreed on other (higher or lower) limits of the liability. The mutual liability did not include accidental event. An exception - increased liability of a hotelkeeper, owner of a ship and innkeeper (including also the case of an accidental event) for keeping property. The partners were not liable for unpredictable accidents or so called force majeure cases which could not be influenced by the responsible party and therefore was exempted from this liability. When claiming liability for delicts (e.g. a theft, illegal action a.o.), an action against the guilty partner could be brought both in respect of a committed delict and the breach of the partnership contract. When being liable for so called quasidelicts (damages to property and bodily injuries caused due to throwing out/pouring out articles/liquids) the partners - owners of the building/apartment, tenants, inhabitants could claim from the co-partners proportional compensation - regarding amounts any of them have paid to a victim. The partners could turn against co-partners for the breach of the undertaken obligations (e.g., for not delivering goods a.o.). For inappropriate management of the financial means of the partnership and their use for personal needs, interest should be paid. There was an exception in respect of the partnership contract - a partner was not entitled to claim more than his copartner are able to pay without applying forced debt deduction - this privilege referred only to the partner - defendant and it could not be transferred to others. Admittance of new partners was limited. If somebody was admitted to the Roman partnership he was a partner (had a direct contractual relations) only in regard to the partner who had invited him To become an equal partner to all partners, the approval of everybody was necessary - amendments to the current partnership contract or conclusion of a new contract.

9. In case of interaction of the concepts of marriage and the partnership contract, the priority usually was given to the concept of marriage. In particular it referred to claims regarding the dowries of the partners' wives/daughters, those claims, with some exceptions, were satisfied in priority. It was common to finance dowry of the partners' daughters from the financial means of the partnership. The Roman marriage as such was considered as some kind of „life's partnership” - ,societas vitae” (lat.), the fact that was correspondingly substantively and procedurally seen in the case of claims brought between the spouses.

10. It was not possible to inherit the status of the partner and a place in the Roman partnership contract. If any of partners died, the partnership ceased to exist - if not agreed otherwise by establishment. An exception - for the purposes to collect partnership's taxes - it could continue to exist also after 
the death of the partner. The heir of the partner was entitled to share in the profit of his predecessor that was supposed to be distributed among the partners after dissolution of the partnership, also losses were binding to the heirs. Even though a heir was not a partner of the partnership, his duty was to improve consequences due to negligence of his predecessor and he had to accomplish things his predecessor has started but has not finished, furthermore any bad faith or intentional harm committed by the deceased had to be taken into account Discredit (infamia - lat.) of personal nature was not transmitted to the heir - the heir was liable solely for the material debts of the deceased. Similarly participation in the partnership contract was not transmitted to the arrogator who through the concept of the arrogation has accepted a partner of the partnership under his power of a father - has conferred to him the status equal to the one of his own child.

11. The partnership contract could terminate when a partner resigns, upon the death, by losing rights of a citizen and because of general poverty. According to the legal definition provided by the jurist Ulpianus (Domitius Ulpianus, ? - 228 A.D.), the partnership ceased to exist: if those who have established it, ceased to exist, upon losing the property of the partnership, according to the will of the partners to dissolve it, by legal actions. The partners terminated the legal existence with the complete or intermediate decrease of legal capacity or upon the death. The property was considered to be lost if nothing was left over from it or its legal status has changed - it ceased to exist, was removed from the civil circulation for sacral purposes, has become publicalienated for the benefit of the Roman nation - state. The partnership ceased to exist if the parties expressed the will to leave it. Due to legal actions the partnership ceased to exist only then when by the agreement of the parties or court ruling its purpose has been changed or legal measures were taken with a purpose to dissolve the partnership. The partnership that was established for a certain goal, ceased to exist by reaching this goal. By ending the partnership contract, joint property rights regarding the property of such partnership were preserved. In distribution of such property special claim was applied (actio communi dividundo - lat.) - an universal claim to divide any joint property. Distribution of the property was performed by an appointed arbiter (arbiter lat.) according to the Roman Civil Procedural rules. Undivided joint property was managed as legally integral combination of undivided share belonging to the parties. It was not possible to force a partner to stay in the partnership, if he did not want that. If there was an agreement not to leave the partnership for some time, the partner who left it prior to the set date and in not favourable economic situation, this partnership withdrawal was valid, but the others were entitled to the compensation. Withdrawal could be performed both by the very partner or his representative.. Also withdrawal notice could be given not only to the very partner but also to his appointed representative (procurator-lat.). If a 
person of unsound mind was a partner, withdrawal rights were transmitted to his trustee.

12. An action or a claim deriving from the partnership contract (actio pro socio - lat.) was a procedural mechanism - ,a claim before court" (actio - lat.), by help of which the partners of the partnership could force their co-partners to fulfil undertaken obligations and achieve protection of their violated interests. A claim belonged to the category in personam (lat.) - it was brought against the respondents who were personally liable according to the concluded agreement (contract) or because of performed illegal actions. A claim was to be reviewed in good faith (bonae fidei - lat.) - a judge had a discretion to interpret legislation and to decide the case by taking into account actual circumstances by observing the principles of justice and honesty. The partnership intervened in the court proceedings as a separate party. From the procedural perspective it was possible to unite connected cases. A claim could be brought against actual not figureconstracting party. The parties were obliged to give security (payment of security deposit). It is known about procedural, in particular about limitation time-limits. A claim could be brought only in case of the partnership contract. As regards an ancillary claim deriving from the partnership contract the partners could bring also other claims resulting from actual circumstances of the case - in respect of the distribution of the joint property, a theft a.o. In case penalties had already been applied to a partner in relation to a separate agreement, right to bring claim deriving from a partnership contract was limited. The partners were entitled to agree that dispute is reviewed by the arbitrator appointed by them. Being recognized to be liable for a claim deriving from a partnership contract included also additional liability for breaching ethical canons - so called concept of „being discredited". (infamia - lat).

13. Roman corporative bodies - associations (universitatis - lat.), colleguims and corporations (collegiis et corporibus - lat.) were artificial subjects of law which existed independently from the existence of a man, they had rights to their autonomous property and their capacity to act was fulfilled with the help of their representatives - natural persons. Before the court a corporative body could be both a claimant and a defendant enjoying the same procedural rights like a natural person. Right to judicial protection was carried out through representatives. Liabilities of the corporative bodies were separated from the private liabilities of their partners - a debt in favour of an association was not a debt in favour of its partners the same as the debt of an association was not a debt of the partners. Three partners were necessary to establish a corporative body; afterwards it maintained its status of autonomous legal subject despite the number of the partners. An association continued to exist also with one remaining partner. The establishment of the corporative bodies was strictly regulated, the approval from the state was needed; the state acted severely in respect of illegally established corporative bodies. 


\section{As regards the research question 2.}

14. Within the reception of provisions of law and the development of the history the principles developed by the ancient Romans have been incorporated also in the modern legislation of the Republic of Latvia which contains following Roman concepts: in respect of limiting/not limiting the duration of the activity of a partnership contract and establishing the time when a contract enters into force, necessity for the party of the legal transaction to express free will and invalidity of a transaction concluded in the result of mistake, a certain form of a partnership contract (a legal transaction) and advantages of the written form, right to include ancillary rules, also introducing the provisions and limitation of the duration of the partnership contract with a temporary goal. Under the Civil Law it is allowed to invest the work of the partner of the partnership, however under the Commercial Law investment in the form of work is forbidden in the equity capital of the modern SIA and AS. According to the Civil Law - an illicit or indecent action, the purpose of which is contrary to religion, laws or moral principles, or which is intended to circumvent the law, may not be the subject-matter of a lawful transaction. No contract which encourages anything illegal, immoral or dishonest shall be binding. The Civil Law partly departs from the Roman principle in respect of the fact that the partnership contract concluded by fraud is void - transaction is not void, it can be contested. The Commercial Law contains the Roman concept to attract an expert to evaluate impact of the partner in the partnership - regarding property contributions in the equity capital of SIA and AS. The Civil Law reflects modified Roman legal traditions - unless otherwise determined by the partnership contract, fungible and consumable property shall be regarded as transferred to the joint ownership of the partners, but non-fungible and inconsumable property - as transferred for use (as regards SIA and AS invested property shall become the property of the company). The Civil Law incorporates the Roman idea regarding limiting division of the partnership's property belonging to the partner - the partner may not require a division while he or she is a partner of the partnership.

15. The Civil Law contains Roman principles in respect of an action with the profit and the losses of the partnership - it is allowed to determine in what proportions the partners shall share in profits and losses, if a contract does not contain rule on that and all contributions have been paid/ evaluated in terms of money, the profits/ losses shall be divided among the partners in proportion to the amount of the contribution of each partner, but if contributions have not been paid/evaluated in terms of money - in equal shares (according to the Commercial Law the amount of the profit of a partner of PS/KS or a shareholder of SIA/AS depends on the proportion of their contribution), establishing conditions regarding the solely distribution of profits or losses, conditions apply both to profits and to losses, it can be agreed that a partner who participates in the partnership only in the terms of an individual 
work, shall share in profit but not in losses; it is not allowed to establish „Lion” type partnership. Similar to the Romans, the Commercial Law provides that $\mathrm{PS} / \mathrm{KS}$ partner has the duty to pay interest if he/she has failed to pay his or her money contribution within a specified period of time, or has not transferred money collected or has taken money from the cashier's office of the partnership without authorisation, a shareholder/ stockholder of SIA/AS has a duty to return the amount acquired without justification; also partners of a modern PS and KS have rights to be reimbursed for losses incurred when handling partnership matters. Regarding PS or KS the Commercial Law contains the concept that a partner has rights to be reimbursed for damages incurred when handling partnership matters and that partnership has an obligation also to pay interest at the legal rate, which shall be calculated from the time the expenditures were incurred.

16. Roman legal traditions are reflected in the provisions of the Commercial Law on unlimited liability of PS partners and KS general partners in respect of the obligations of the partnership, the right of all partners of PS to represent the partnership, unless they have been excluded from representation, usefulness of the joint representation and rights to determine such joint representation, in the Civil Law regarding rights to agree to assign the handling of partnership matters to one/several partners or to the third persons and in the provision that transactions entered into by the agents within the limits of their authority shall be binding without limitation and solidarily, except in cases where otherwise agreed with third persons. Regarding limiting the authorisation of the agents, the Civil Law under influence of the Roman traditions, allow restricting such authorisation, however the Commercial Law as a special law does not accept authorisation's restrictions regarding the third persons. According to the Civil Law and the Commercial Law, to take a decision the consent of all the partners of the partnership or majority of votes shall be necessary. The impact of the Roman traditions can be observed in the provisions of the Commercial Law on the right of PS partner/ KS general partner to refuse to satisfy a claim by a creditor while the PS/KS has a right to contest the transaction which is the basis of the obligation or the creditor may satisfy the claim by an off-set, and on the basis of an adjudication which has come into legal effect in a matter, in which the defendant is the partnership, collection may not be made against the property of PS partner/KS general partner. The Roman traditions are reflected in the provisions of the Civil Law that regarding a contract entered into without authorisation by the other partners, liable shall be only such partners who have entered into the contract (Commercial Law contains modification of Roman tradition - a partnership contract may specify that all or several partners of PS are entitled to only jointly to represent the partnership, where a partner enters into a transaction with a third person in his or her own name, he or she alone shall be liable to such third person, a joint debtor may propose as set-off only his or her own 
counterclaims against the creditor unless the joint debtors are in a partnership relationship.

17. Contrary to the Roman approach admittance of a new partner to already existing PS or KS is possible, however similar to the Romans, approval of all involved parties is necessary for admitting a new partner. The Civil Law continues Roman tradition - a partnership is terminated upon the death of a partner, however if a partnership contract stipulates that the partnership shall continue the deceased partner shall be regarded as withdrawn one. If a partnership terminates upon the death of a partner, the heirs of the deceased person shall immediately notify other partners about the death and continue the estate-leaver's affairs pending the provision of further instructions by the partnership or the liquidator. According to the Civil Law a duty to compensate losses shall pass to the heirs of the person who has caused these losses, unless otherwise provided for by the law. The Commercial Law reflects modified impact of the Roman principles - in the case of the death of a partner of PS/KS, his or her heir has the right to become a partner of the partnership, if this is specified in the partnership contract or all partners of the partnership agree to it. If a heir does not wish to/cannot become a partner of the partnership, or the other partners do not agree to it, the heir has a right to receive that which in conformity with his or her part of the estate would have been due to the deceased partner of the partnership at the time of the opening of the succession. Similar to Roman times, according to the Civil Law a partnership shall cease if all the partners agree thereto or a partner gives notice with respect to the partnership contract - in case this contract does not provide ongoing existence of the partnership after such notice. A provision of a contract whereby the right to give notice is not allowed shall not be valid. The Commercial Law provides right of the partners of PS/KS to withdraw from the partnership, providing a notice of termination. According to the Civil Law it is forbidden to give notice in bad faith - otherwise such partner shall be held liable for losses and the partner shall not share in the profit the partnership acquired after such notice. The Civil Law provides the right of a partner for good cause, to request termination of the partnership. If a partnership terminates otherwise than through giving notice, the right of handling matters of a partner shall be regarded as still subsisting until the time when he or she comes to know of the termination, or when he or she should have known of such termination. The Commercial Law provides that a PS/KS terminates by the decision of the partners of the partnership. The Civil Law provides that a partnership terminates if concursus proceedings are initiated or administration is established with respect to partner's property, as well as the right of a creditor, in executing a court judgment, to give notice on the behalf of a partner, distrain the contribution and perform collection. However in comparison with the Romans it is allowed to continue partnership contract if so provided in this contract. The Commercial Law provides - the declaration of the partner of the 
partnership as insolvent is the ground for withdrawal - if not provided otherwise in the contract. The Civil Law provides the right of the state authority (,government") to prohibit the further existence of the partnership. The Commercial Law provides termination by the court ruling. The Civil Law provides that a partnership shall be terminated if the goal set for the partnership is achieved, when liquidating the partnership rules on distribution of joint property shall be applied, joint owners have the right to require the division of the common property and to alienate or pledge the share of the common property belonging to them.

18. The Civil Law has adopted the Roman conception about the gradation and levels of civil liability. Limit of liability among the partners goes to an ordinary negligence, excluding liability for an accidental event and force majeure (with an exception to e.g. hotel keepers a.o. - they are responsible also in case of an accidental event). The Civil Law provides for mutual off-set in the situation of bilateral negligence and forbids mutual claims in the event of fraud or evil intention. A contract whereby someone has negotiated something for oneself for refraining from an illegal action or merely for performing one's duty shall not be binding. It is possible to declare invalid transaction concluded by fraud - unlike the Romans, such transactions are not automatically regarded as void. The Civil Law contains a negative attitude characteristic to Roman tradition in respect of the obligations arising from gambling - they enjoy neither protection by law, nor judicial protection.

19. The Civil Law has inherited the Roman concepts that accidental loss shall not be compensated, that each of the joint debtors may be forced to perform the whole obligation, and their performance shall release the others and that it depends on a debtor 's discretion as to which of several joint creditors will perform an obligation, that the one who has instructed to perform an illicit act shall be liable for it, notwithstanding that the acts of such person exceed the limits of the instructions, that the one who fails to exercise due care in choosing servants a.o. employees, shall be liable for losses they have caused, that the bailee who undertakes to keep the property without compensation, shall be liable only for malicious intent or gross negligence and that it is possible voluntarily to increase limits of liability to an accidental event (for Romans this limit was lower - to negligence). According to the Roman legal tradition the concept of dowry is regulated in the Civil Law as well as right of spouses to bring claims against each other. The Civil Law provides that all obligations, other than exclusively personal ones, shall devolve to the heir. The Civil Law provides for guardianship established over the persons lacking capacity to act due to mental illness or mental deficiency. In the Civil Law in a transformed form exist traditions of the concept - under power of father (patria potestas lat.) - child is under ,the custody" of his or her parents (until 01.01.2003. „under power of parents"), parents are not liable for obligations entered into, without the consent of their parents, by minors who are in the custody of their 
parents, unless they themselves have not gained some benefit therefrom. According to the Civil Law lawful transactions can be made also through substitutes.

20. The Civil Law also provides that a partner may bring an action, in his or her own name, against any co-partner with respect to the performance of the duties assumed under the partnership contract. Under the provisions of the Commercial Law PS/KS can be both a claimant and a defendant before the court, collection on the property of a partnership may be commenced only after a court ruling in a matter in which the defendant is the partnership. Modern Latvian legislation contains Roman conception about procedural time-limits, tradition to unite related proceedings, tradition to define in law the courts action regarding applying of legislation, the right to bring a counterclaim, the concept of settlement is incorporated as well as imposing of penalties is over taken - as a special concept of contractual penalties. Nowadays in the most cases the contracting parties are entitled to agree on court of arbitration. Live is also Roman idea about restricting the right to bring an action in general court if parties have agreed to transfer the dispute to arbitration court. The principle of juridical ethics has derived from the Roman legal tradition - nobody could be recognized to be guilty before he/she is sentenced and the court judgement has not entered into lawful effect - so called ,presumption of innocence”. Procedural legislation has accepted Roman tradition to use system of several court instances. We can be thankful to the Romans for present axiom in criminal law regarding the meaning of the subjective side of the crime in its qualification.

21. Legal structure of modern Latvian capital companies (SIA, AS) and associations are based on the Roman principles - they as legal entities with their property separated from the private property of their shareholders (stockholders, partners) conclude legal transactions through their lawful representatives - members of the board The capital company continues to exist as the legal entity also after changes made in the structure of shareholders/stockholders despite the number of remaining shareholders/stockholders. In relation to the Roman partnership we can speak about the beginning of the limited liability concept when capital company or association is not liable for shareholders' obligations and shareholders are not liable for obligations of the capital company or association. Also Latvian procedural legislation recognizes equal civil-procedural legal capacity and capacity to act of legal entities (capital companies (SIA, AS), associations a.o.) and of natural persons. In the court proceeding the legal entities are represented by their officials or other authorized persons. Person represented may at any time withdraw the authorisation given to its representative. A representative has the right to perform, on behalf of the person represented, all procedural actions, except those that require special authorisation. Similar to the Romans special authorisation inter alia is necessary for submitting execution documents for 
recovery, receiving property or money adjudged. As regards the legitimacy of the decision making bodies (meeting of stockholders, partners and shareholders) of modern Latvian associations and capital companies applied is Roman concept about quorum. The Roman principles form the basis of the operation of boards of the capital companies. Also the legislators of modern democratic countries are familiar with the right of the state power within the context of law and according to the order provided by the law to act against legal entities endangering legality.

Accordingly the goals and the tasks of the research are considered to be accomplished and proposed research questions to be fully reviewed and analysed.

At the same time taking into account the ancient and successful traditions in using the Roman legal principles to develop national legislation, it would be useful to use the legal concepts of the ancient Romans in order to improve the legal environment of the Republic of Latvia also in the future. In that regard the author allows himself to express several propositions:

In order to promote the business activities of the individuals, it would be possible to return to the Roman approach in respect of contributing partner's work in the partnership. As it is known the Civil Law contains provisions of the Roman origin stipulating contribution of work (D 17.2.5.1; C 4.37.1 vs CL 2243) but it is forbidden to contribute shareholder's work in the equity capital of the modern SIA and AS (KoL 151 (1); KoL 153 (2)) - obligations to provide services or to perform work may not be the subject of the property contribution. However, already the Roman jurists drew attention to the fact that the work performed for the benefit of a partnership shall have economic value "with work [..] the lack of the property can be compensated" (D 17.2.5.1). Thus also in nowadays it would be possible to develop legal constructions in regard to the contribution of work in the equity capitals of the capital companies, at least regarding limited liability companies (SIA).

For this purpose the work (obligation of the founders to provide services and/or to perform work) could be recognized as an eligible subject of the property contribution by amending correspondingly Article 153 (2) in the Commercial Law and introducing regulation in relation to the juridical nuances deriving from such amendments. The Commercial Law Article 143 - regarding the provisions of the memorandum of association - should be amended too, by defining precisely the nature, amount a.o. of services provided and/or performed work. Obviously it would be appropriate to determine the total amount of such kind of property contribution - it could be the same as the one provided in the Commercial Law Article 154 (2) (not exceeding 5700 euro and in any case less than one-half of the equity capital of the SIA to be founded), thus the evaluation of the contribution could be made by the founders ((KoL 154 (2)). It would be necessary to establish the time-limit within which 
the obligations to provide services and/or perform work shall be fulfilled -it could be analogical to the one provided in the Commercial Law Article 146 (2) - within one year from the date when the company was entered in the Commercial Register. Until the fulfilment of those obligations shares paid in the terms of the contribution of work shall be considered as subscribed but not paid-up (KoL 143 (1) 4), 5); KoL 146 (1)), including all following consequences in respect of the rules of subscription and payment of the equity capital (KoL 146 (2)), failure to pay in due time (KoL 156), restrictions of the right to alienate (KoL 188 (4)), restrictions on voting rights of a shareholder (KoL 211(1)) a.o. In order to protect interests of SIA creditors' constructions similar to the ones mentioned in the Commercial Law Article 185. ${ }^{1}(7)$ could be introduced, establishing joint liability of the shareholders for obligations in the case SIA is declared insolvent - shares to be paid in the terms of the contribution of work in the amount of unpaid value until the moment they are actually paid-up - obligations to provide services and/or perform work are fulfilled.

In that regard it would be necessary to make the following amendments in the Commercial Law:

1. To include in point 6 of the first paragraph of Article 143 after the words ,indicating each item of the property contribution” the following text "(in case the subject of the property contribution is obligations to provide services and/or to perform work (Article 153. ${ }^{1}$ of this Law) - the nature, amount and time-limits of the performance of the provided services and/or performed work shall be indicated)".

\section{as follows:}

Accordingly point 6 of the first paragraph of Article 143 would read

„6) the number of and the nominal value total of those shares which, when founding the company, are to be paid-up with property contributions, indicating each item of the property contribution (in case the subject of the property contribution is obligations to provide services and/or to perform work (Article 153. ${ }^{l}$ of this Law) - the nature, amount and time-limits of the performance of the provided services and/or performed work shall be indicated), and the given name, surname, personal identity number (if the person does not have a personal identity number - the date of birth, the number and date of issue of a personal identification document, the state and authority, which issued the document) and residential address of those persons who have assumed obligations to make property contributions;"

\section{To include the following new paragraph $2^{2}$ in Article 146:}

,(2. $\left.{ }^{2}\right)$ In case the equity capital of the limited liability company partly is paid by property contribution the subject of which is obligations to provide services and/or to perform work (Article 153. ' ${ }^{\prime}$ of this Law), the equity capital shall be signed fully by the submission of the application for registration, the part paid in the terms of property contribution shall be paid within one year 
from the date when the company was entered in the Commercial Register, the part paid in money shall be paid-up up to the submission of the application for registration."

3. To include in the second paragraph of Article 153 after words "to perform work" the following text ,, (except the case provided in Article 153. 'of this Law)".

\section{follows:}

Accordingly the second paragraph of Article 153 would read as

„(2) Obligations to provide services or to perform work (except the case provided in Article 153. ${ }^{I}$ of this Law), unanticipated profits or anticipated activities for the company, or also expected salary, honoraria, dividends and similar payments, which a founder or shareholder may receive from the company, may not be property contributions."

\section{To include the following new Article 153. ${ }^{1}$ :}

„Article 153. ${ }^{1}$. Contribution of work in the equity capital of the limited liability company.

(1) When founding a limited liability company, obligations to provide services and/or to perform work may be property contribution in case all of the following conditions are satisfied:

1) the founders of the company are at least two natural persons;

2) the value of such property contribution does not exceed 5700 euro and property contribution is less than one-half of the equity capital of the company;

3) only one of the founders shall make such property contribution, there is one such property contribution in the equity capital of the company to be founded and the remaining equity capital is paid up only in money;

4) the founder of the company who shall pay the equity capital in the terms of such property contribution, does not pay equity capital of the company in money.

(2) The time-limit of the execution of the obligations stated in the first paragraph of this Article shall not exceed time-limits stated in the paragraph $2 .^{2}$ of Article 146 in respect of payment of share of the equity capital with property contribution.

(3) Regarding the actual fulfilment of the obligations stated in the first paragraph of this Article all shareholders compose and sign an act containing the reference to the memorandum of association and description of the provided services and/or performed work, their amount, evaluation in the terms of money, time-limit for actual fulfilment, as well as the given name, surname, personal identity number (if the person does not have a personal identity number - the date of birth, the number and date of issue of a personal identification document, the state and authority, which issued the document) and residential address of the person who has assumed obligations to make 
property contribution by providing services and/or performing work. Each shareholder of the company shall have one copy of this act, one copy of this act shall be submitted to the board of the company."

\section{To include the following paragraph 2. ${ }^{2}$ in Article 154:}

, $\left(2^{2}\right)$ In case when founding a limited liability company, the subject of the property contribution is obligations to provide services and/or to perform work

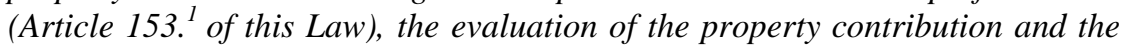
submission of an opinion may be made by the founders. In this case, all founders shall sign the opinion."

\section{To include the following paragraph 3. ${ }^{5}$ in Article 154:}

, $\left(3^{5}\right)$ If the subject of the property contribution is obligations to provide services and/or to perform work (Article 153. ${ }^{l}$ of this Law), the value of the property contributions shall be determined by taking into account an average market value for providing similar services and/or performing work within the period of six months prior to the evaluation."

7. To include in the fourth paragraph of Article 154 after words ,the types of commercial activities of the company" the following text: "If the subject of the property contribution is obligations to provide services and/or to perform work (Article 153. ${ }^{\text {I }}$ of this Law) - a description of the provided services and/or performed work, their amount, time-limit for actual fulfilment, as well as the given name, surname, personal identity number (if the person does not have a personal identity number - the date of birth, the number and date of issue of a personal identification document, the state and authority, which issued the document) and residential address of the person who has assumed obligations to make property contributions shall be indicated."

8. To include in the fourth paragraph of Article 154 after words and a figure ,in paragraph $2 .{ }^{1}$ of this Article” the following text ,and paragraph 2. ${ }^{2}$,, as well as to replace the text ,the property contribution referred to" with the following text ,the property contributions referred to."

Accordingly the fourth paragraph of Article 154 would read as follows:

,(4) An opinion regarding the valuation of a property contribution shall include a description and value of each contribution item, indicate the ownership of the property, and the method used for the valuation of each contribution, and include an opinion regarding the conformity of the items of property contribution with the types of commercial activities of the company. If the subject of the property contribution is obligations to provide services and/or to perform work (Article 153. ${ }^{1}$ of this Law) - a description of the provided services and/or performed work, their amount, time-limit for actual fulfilment, as well as the given name, surname, personal identity number (if the person does not have a personal identity number - the date of birth, the number and date of issue of a personal identification document, the state and authority, which issued the document) and residential address of the person who has assumed obligations to make property contributions shall be indicated. If the 
valuation is made by the founders or shareholders, the valuation methods for property contributions need not be indicated. The information used as the basis for determination of the value of property contribution shall be indicated additionally in the opinion regarding the valuation of the property contributions referred to in paragraph 2. ${ }^{1}$ and paragraph $2 .{ }^{2}$ of this Article which is drawn up by founders or shareholders."

9. To include the following paragraph 1. ${ }^{1}$ in Article 156:

, $\left(1^{1}\right)$ If subscribed shares of a limited liability company shall be paid by property contribution the subject of which is obligations to provide services and/or to perform work (Article 153. 'of this Law) and the board establishes that the stated obligations are not fulfilled within the period provided in the memorandum of association, shares shall be paid in money by applying timelimits and procedure provided for in the first paragraph of this Article, in case these time-limits are not observed, provisions of the second paragraph of this Article shall apply."

\section{To include the following Article 166.'}

\section{„Article 166. ${ }^{\text {. }}$. Liability in the case of work contribution.}

If the equity capital of a limited liability company partly is paid by property contribution the subject of which is obligations to provide services and/or to perform work (Article 153. ' of this Law) and the company is declared insolvent prior to fulfilment of those obligations, shareholders shall be solidarily liable for obligations of the company the total amount of which does not exceed the difference between the amount of the equity capital stated in Article 185 of this Law and amount of the paid equity capital by the founders."

11. To include in the fourth paragraph of Article 188 after words ,,as joint debtors" the following text ,(if according to memorandum of association, share shall be paid by property contribution the subject of which is obligations to provide services and/or to perform work (Article 153. 'of this Law), when establishing liability, it shall be presumed that the share shall be paid by money)."

Accordingly the fourth paragraph of Article 188 would read as follows:

„(4) Only fully paid-up shares may be alienated, unless it has been otherwise specified in the articles of association. In case of alienation of shares, which have not been paid up, the alienator and acquirer shall be responsible for paying up of shares as joint debtors (if according to memorandum of association, share shall be paid by property contribution the subject of which is obligations to provide services and/or to perform work (Article 153. ' of this Law), when establishing liability, ii shall be presumed that the share shall be paid by money)."

\section{To include the following paragraph $1 .^{1}$ in Article 191:}

, $\left(1^{1}\right)$ If the equity capital of a limited liability company partly is paid by property contribution the subject-matter of which is obligations to provide 
services and/or to perform work (Article 153. 'of this Law) in the case of the death of the shareholder having those obligations, his or her heirs shall have a duty to pay the value of the signed but not paid shares of this shareholder in terms of money according to the valuation stated in memorandum of association and to the opinion regarding the valuation of a property contribution." 


\section{LIST OF THE SOURCES USED IN THE SUMMARY}

\section{Roman law primary sources}

1. C 1.12.6.8 LEO A. ERYTHRIO PP.

2. C 2.11.22 DIOCL. ET MAXIM. AA. ET CC. DOMITIANO

3. C 3.37 .3 pr. ALEX. A. VERECUNDIANO

4. C 3.37.3.1 ALEX. A. VERECUNDIANO.

5. C 3.37.5 DIOCL. ET MAXIM. AA. ET CC. SECUNDINO.

6. C 3.38.2 ALEX. A. EUPHRATAE.

7. C 4.26.12 DIOCL. ET MAXIM. AA. ET CC. VICTORI

8. C 4.37.1 DIOCL. ET MAXIM. AA. ET CC AURELIO

9. C 4.37.2 DIOC. ET MAXIM. AA. ET CC. PANNONIO

10. C 4.37.3 DIOCL. ET MAXIM. AA. ET CC. AURELIO VICTORINO MIL

11. C 4.37.4 DIOCL. ET MAXIM. AA. ET CC. AURELIO CELERI.

12. C 4.37.5 DIOCL. ET MAXIM. AA. ET CC. AURELIO THEODORO

13. C 4.37.6 IUST. A. IOHANNI PP

14. C 4.37.7 IUST. A IOHANI PP

15. C 6.22 .1 pr. GORD. A. PETRONIO MIL.

16. C 7.40.1.1c IUST. A. IULIANO PP.

17. C 7.40.1.1d IUST. A. IULIANO PP.

18. C 7.40.1.1e IUST. A. IULIANO PP.

19. C 8.10.4 PHILIPP. A. ET PHILIPP. C. VICTORI

20. C 8.10.5 DIOCL. ET MAXIM. AA. OCTAVIO.

21. C 8.17.11 pr. LEO A. ERYTHRIO PP

22. C 9.20.6 DIOCL. ET MAXIM. AA. MARCIANAE

23. C 10.14.1 CONSTANTIUS A. ORIONI COM. RER. PRIVAT.

24. D 2.11.5 pr. Paulus libro 69 ad edictum

25. D 2.11.5.1 Paulus libro 69 ad edictum

26. D 2.13.9 pr. Paulus libro tertio ad edictum

27. D 2.14.7.1 Ulpianus libro quarto ad edictum

28. D 2.14.14 Ulpianus libro quarto ad edictum

29. D 2.14.24 Paulus libro tertio ad Plautium

30. D 2.14.25 pr. Paulus libro tertio ad edictum

31. D 2.14.27 pr.Paulus libro tertio ad edictum

32. D 3.2.1 Iulianus libro primo ad edictum

33. D 3.2.6.1 Ulpianus libro sexto ad edictum

34. D.3.2.6.4 Ulpianus libro sexto ad edictum

35. D 3.2.6.6 Ulpianus libro sexto ad edictum

36. D 3.2.6.7 Ulpianus libro sexto ad edictum

37. D 3.2.7 Paulus libro quinto ad edictum

38. D 3.2.13.5 Ulpianus libro sexto ad edictum

39. D 3.4.1 pr. Gaius libro tertio ad edictum provinciale

40. D 3.4.1.1 Gaius libro tertio ad edictum provinciale

41. D 3.4.1.2 Gaius libro tertio ad edictum provinciale

42. D 3.4.1.3 Gaius libro tertio ad edictum provinciale

43. D 3.4.2 Ulpianus libro octavo ad edictum 
44. D 3.4.3 Ulpianus libro nono ad edictum

45. D 3.4.4 Paulus libro nono ad edictum

46. D 3.4.5. Ulpianus libro octavo ad edictum

47. D 3.4.6 pr. Paulus libro nono ad edictum

48. D 3.4.6.1 Paulus libro nono ad edictum

49. D 3.4.6.2 Paulus libro nono ad edictum

50. D 3.4.6.3 Paulus libro nono ad edictum

51. D 3.4.7 pr. Ulpianus libro decimo ad edictum

52. D 3.4.7.1 Ulpianus libro decimo ad edictum

53. D 3.4.7.2 Ulpianus libro decimo ad edictum

54. D 3.4.8 Iavolenus libro 15. ex Cassio

55. D 3.4.9 Pomponius libro 13. ad Sabinum

56. D 3.4.10 Paulus libro primo manualium

57. D 3.5.7.3 Ulpianus libro decimo ad edictum

58. D 3.5.20.2 Paulus libro nono ad edictum

59. D 3.5.39 Paulus libro decimo ad Sabinum

60. D 4.3.20.1 Paulus libro 11 ad edictum

61. D 4.4.6 Ulpianus libro decimo ad edictum

62. D 4.4.7.1 Ulpianus libro 11 ad edictum

63. D 4.4.16.1 Ulpianus libro 11 ad edictum

64. D 4.8.34 pr. Paulus libro 13 ad edictum

65. D 4.8.34.1 Paulus libro 13 ad edictum

66. D 4.9.6.1 Paulus libro 22 ad edictum

67. D 9.3.1pr. Ulpianus libro 23 ad edictum

68. D 9.3.1.10 Ulpianus libro 23 ad edictum

69. D 9.3.2 Gaius libro sexto ad edictum provinciale

70. D 9.3.3 Ulpianus libro 23 ad edictum

71. D 9.3.4 Paulus libro 19 ad edictum

72. D 9.4.1 pr. Gaius libro secundo ad edictum provinciale

73. D 9.4 .2 pr. Ulpianus libro 18 ad edictum

74. D 9.4.8 Ulpianus libro 37 ad edictum

75. D 9.4.9 Paulus libro 39 ad edictum

76. D 9.4.10 Paulus libro 22 ad edictum

77. D 10.2.39.3 Scaevola libro primo responsorum

78. D 10.3.1 Paulus libro 23 ad edictum

79. D 10.3.2 pr. Gaius libro septimo ad edictum provinciale

80. D 10.3.14.3 Paulus libro tertio ad Plautium

81. D 10.3.14.4 Paulus libro tertio ad Plautium

82. D 10.3.16 Paulus libro sexto ad Plautium

83. D 10.3.15. Paulus libro quinto ad Plautium

84. D 12.1.16 Paulus libro 32 ad edictum

85. D 12.2.13.4 Ulpianus libro 22 ad edictum

86. D 12.2.28.4 Paulus libro 18 ad edictum

87. D 13.6.5.2 Ulpianus libro 28 ad edictum

88. D 14.1.1 pr. Ulpianus libro 28 ad edictum

89. D 14.1.1.1 Ulpianus libro 28 ad edictum

90. D 14.1.1.2 Ulpianus libro 28 ad edictum 
91. D 14.1.1.3 Ulpianus libro 28 ad edictum

92. D 14.1.1.4 Ulpianus libro 28 ad edictum

93. D 14.1.1.4 Ulpianus libro 28 ad edictum

94. D 14.1.1.5 Ulpianus libro 28 ad edictum

95. D 14.1.1.7 Ulpianus libro 28 ad edictum

96. D 14.1.1.12 Ulpianus libro 28 ad edictum

97. D 14.1.1.13 Ulpianus libro 28 ad edictum

98. D 14.1.1.14 Ulpianus libro 28 ad edictum

99. D 14.1.1.15 Ulpianus libro 28 ad edictum

100. D 14.1.1.17 Ulpianus libro 28 ad edictum

101. D 14.1.1.20 Ulpianus libro 28 ad edictum

102. D 14.1.1.24 Ulpianus libro 28 ad edictum

103. D 14.1.1.25 Ulpianus libro 28 ad edictum

104. D 14.1.2 Gaius libro nono ad edictum provinciale

105. D 14.1.3 Paulus libro 29 ad edictum

106. D 14.1.4 pr. Ulpianus libro 29 ad edictum

107. D 14.1.4.1 Ulpianus libro 29 ad edictum

108. D 14.1.4.2 Ulpianus libro 29 ad edictum

109. D 14.1.5.2 Paulus libro 29 ad edictum

110. D 14.1.6 pr. Paulus libro sexto brevium

111. D 14.1.6.1 Paulus libro sexto brevium

112. D 14.3.1 Ulpianus libro 28 ad edictum

113. D 14.3.2 Gaius libro nono ad edictum provinciale

114. D 14.3.3 Ulpianus libro 28 ad edictum

115. D 14.3.4 Paulus libro 30 ad edictum

116. D 14.3 .5 pr. Ulpianus libro 28 ad edictum

117. D 14.3.5.1 Ulpianus libro 28 ad edictum

118. D 14.3.5.2 Ulpianus libro 28 ad edictum

119. D 14.3.5.3 Ulpianus libro 28 ad edictum

120. D 14.3.5.4 Ulpianus libro 28 ad edictum

121. D 14.3.5.5 Ulpianus libro 28 ad edictum

122. D 14.3.5.6 Ulpianus libro 28 ad edictum

123. D 14.3.5.7 Ulpianus libro 28 ad edictum

124. D 14.3.5.8 Ulpianus libro 28 ad edictum

125. D 14.3.5.9 Ulpianus libro 28 ad edictum

126. D 14.3.5.10 Ulpianus libro 28 ad edictum

127. D 14.3.5.11 Ulpianus libro 28 ad edictum

128. D 14.3.5.12 Ulpianus libro 28 ad edictum

129. D 14.3.6 Paulus libro 30 ad edictum

130. D 14.3.11.6 Ulpianus libro 28 ad edictum

131. D 14.3.13.2 Ulpianus libro 28 ad edictum

132. D 14.3.14 Paulus libro quarto ad Plautium

133. D 14.3.18 Paulus libro singulari de variis lectionibus

134. D 14.3.19.1 Papinianus libro tertio responsorum

135. D 14.6.2 Ulpianus libro 64 ad edictum

136. D 15.1.11.9 Ulpianus libro 29 ad edictum

137. D 15.1.13 Ulpianus libro 29 ad edictum 
138. D 15.1.15 Ulpianus libro 29 ad edictum

139. D 15.1.19.2 Ulpianus libro 29 ad edictum

140. D 15.1.20 Paulus libro 30 ad edictum

141. D 15.1.27.8 Gaius libro nono ad edictum provinciale

142. D 15.1.51 Scaevola libro secundo quaestionum

143. D 15.3.1 pr. Ulpianus libro 29 ad edictum

144. D 15.3.13 Ulpianus libro 29 ad edictum

145. D 15.3.14 Iulianus libro 11 digestorum

146. D 16.1.1 pr. Paulus libro 30 ad edictum

147. D 16.1.17.2 Africanus libro quarto quaestionum,

148. D 16.2.9 pr. Paulus libro 32 ad edictum

149. D 16.2.9.1 Paulus libro 32 ad edictum

150. D 16.2.10 pr. Ulpianus libro 63 ad edictum

151. D 16.2.10 1. Ulpianus libro 63 ad edictum

152. D 16.3.1.6 Ulpianus libro 30 ad edictum

153. D 17.2.1. pr. Paulus libro 32. ad edictum

154. D 17.2.1.1 Paulus libro 32. ad edictum

155. D 17.2.2 Gaius libro decimo ad edictum provinciale

156. D 17.2.3 pr. Paulus libro 32. ad edictum

157. D 17.2.3.1 Paulus libro 32. ad edictum

158. D 17.2.3.2 Paulus libro 32. ad edictum

159. D 17.2.3.3 Paulus libro 32. ad edictum

160. D 17.2.4 pr. Modestinus libro tertio regularum

161. D 17.2.4.1 Modestinus libro tertio regularo

162. D 17.2.5. pr. Ulpianus libro 31. ad edictum

163. D 17.2.5.1 Ulpianus libro 31. ad edictum

164. D 17.2.5.2 Ulpianus libro 31. ad edictum

165. D 17.2.6 Pomponius libro nono ad Sabinum

166. D 17.2.7 Ulpianus libro 30. ad Sabinum

167. D 17.2.8 Paulus libro sexto ad Sabinum

168. D 17.2.9 Ulpianus libro 30. ad Sabinum

169. D 17.2.10 Paulus libro sexsto ad Sabinum

170. D 17.2.11 Ulpianus libro 30. ad Sabinum

171. D 17.2.12 Paulus libro sexto ad Sabinum

172. D 17.2.13 Paulus libro 32. ad edictum

173. D 17.2.14 Ulpianus libro 30. ad Sabinum

174. D 17.2.15 Pomponius libro 13. ad Sabinum

175. D 17.2.16 pr. Ulpianus libro 30. ad Sabinum

176. D 17.2.16.1 Ulpianus libro 30. ad Sabinum

177. D 17.2.17 pr. Paulus libro sexto ad Sabinum

178. D 17.2.17.1 Paulus libro sexto ad Sabinum

179. D 17.2.17.2 Paulus libro sexto ad Sabinum

180. D 17.2.18 Pomponius libro 13. ad Sabinum

181. D 17.2.19 Ulpianus libro 30. ad Sabinum

182. D 17.2.20 Ulpianus 31. ad edictum

183. D 17.2.21 Ulpianus libro 30. ad Sabinum

184. D 17.2.22 Gaius libro decimo ad edictum provinciale 
185. D 17.2.23 pr. Ulpianus libro 30. ad Sabinum

186. D 17.2.23.1 Ulpianus libro 30. ad Sabinum

187. D 17.2.24 Ulpianus libro 31. ad edictum

188. D 17.2.25 Paulus libro sexto ad Sabinum

189. D 17.2.26 Ulpianus libro 31. ad edictum

190. D 17.2.27 Paulus libro sexto ad Sabinum

191. D 17.2.28 Paulus libro 60. ad edictum

192. D 17.2.29 pr. Ulpianus libro 30. ad Sabinum

193. D 17.2.29.1 Ulpianus libro 30. ad Sabinum

194. D 17.2.29.2 Ulpianus libro 30. ad Sabinum

195. D 17.2.30 Paulus libro sexto ad Sabinum

196. D 17.2.31 Ulpianus libro 30. ad sabinum

197. D 17.2.32 Ulpianus libro secundo ad edictum

198. D 17.2.33 Ulpianus libro 31. ad edictum

199. D 17.2.34 Gaius libro decimo ad edictum provinciale

200. D 17.2.35 Ulpianus libro 30. ad Sabinum

201. D 17.2.36 Paulus libro sexto ad Sabinum

202. D 17.2.37 Pomponius libro 13. ad Sabinum

203. D 17.2.38 pr. Paulus libro sexto ad Sabinum

204. D 17.2.38.1 Paulus libro sexto ad Sabinum

205. D 17.2.39 Pomponius libro 13. ad Sabinum

206. D 17.2.40 Pomponius libro 17. ad Sabinum

207. D 17.2.41 Ulpianus libro 20. ad edictum

208. D 17.2.42 Ulpianus libro 45.ad Sabinum

209. D 17.2.43 Ulpianus libro 28. ad edictum

210. D 17.2.44 Ulpianus libro 31. ad edictum

211. D 17.2.45 Ulpianus libro 30. ad Sabinum

212. D 17.2.46 Paulus libro sexto ad Sabinum

213. D 17.2.47 pr. Ulpianus libro 30. ad Sabinum

214. D 17.2.47.1 Ulpianus libro 30. ad Sabinum

215. D 17.2.48 Paulus libro sexto ad Sabinum

216. D 17.2.49 Ulpianus libro 31. ad edictum

217. D 17.2.50 Paulus libro sexto ad Sabinum

218. D 17.2.51 pr. Ulpianus libro 30. ad Sabinum

219. D 17.2.51.1 Ulpianus libro 30. ad Sabinum

220. D 17.2.52 pr. Ulpianus libro 31. ad edictum

221. D 17.2.52.1 Ulpianus libro 31. ad edictum

222. D 17.2.52.2 Ulpianus libro 31. ad edictum

223. D 17.2.52.3 Ulpianus libro 31. ad edictum

224. D 17.2.52.4 Ulpianus libro 31. ad edictum

225. D 17.2.52.5 Ulpianus libro 31. ad edictum

226. D 17.2.52.6 Ulpianus libro 31. ad edictum

227. D 17.2.52.7 Ulpianus libro 31. ad edictum

228. D 17.2.52.8 Ulpianus libro 31. ad edictum

229. D 17.2.52.9 Ulpianus libro 31. ad edictum

230. D 17.2.52.10 Ulpianus libro 31. ad edictum

231. D 17.2.52.11 Ulpianus libro 31. ad edictum 
232. D 17.2.52.12 Ulpianus libro 31. ad edictum

233. D 17.2.52.13 Ulpianus libro 31. ad edictum

234. D 17.2.52.14 Ulpianus libro 31. ad edictum

235. D 17.2.52.15 Ulpianus libro 31. ad edictum

236. D 17.2.52.16 Ulpianus libro 31. ad edictum

237. D 17.2.52. 17 Ulpianus libro 31. ad edictum

238. D 17.2.52.18 Ulpianus libro 31. ad edictum

239. D 17.2.53 Ulpianus libro 30. ad Sabinum

240. D 17.2.54 Pomponius libro 13. ad Sabinum

241. D 17.2.55 Ulpianus libro 30. ad Sabinum

242. D 17.2.56 Paulus libro sexto ad Sabinum

243. D 17.2.57 Ulpianus libro 30. ad Sabinum

244. D 17.2.58 pr. Ulpianus libro 31. ad edictum

245. D 17.2.58.1 Ulpianus libro 31. ad edictum

246. D 17.2.58.2 Ulpianus libro 31. ad edictum

247. D 17.2.58.3 Ulpianus libro 31. ad edictum

248. D 17.2.59 pr. Pomponius libro 12. ad Sabinum

249. D 17.2.59.1 Pomponius libro 12. ad Sabinum

250. D 17.2.60 pr. Pomponius libro 13. ad Sabinum

251. D 17.2.60.1 Pomponius libro 13. ad Sabinum

252. D 17.2.61 Ulpianus libro 31. ad edictum

253. D 17.2.62 Pomponius libro 13. ad Sabinum

254. D 17.2.63 pr. Ulpianus libro 31. ad edictum

255. D 17.2.63.1 Ulpianus libro 31. ad edictum

256. D 17.2.63.2 Ulpianus libro 31. ad edictum

257. D 17.2.63.3 Ulpianus libro 31. ad edictum

258. D 17.2.63.4 Ulpianus libro 31. ad edictum

259. D 17.2.63.5 Ulpianus libro 31. ad edictum

260. D 17.2.63.6 Ulpianus libro 31. ad edictum

261. D 17.2.63.7 Ulpianus libro 31. ad edictum

262. D 17.2.63.8 Ulpianus libro 31. ad edictum

263. D 17.2.63.9 Ulpianus libro 31. ad edictum

264. D 17.2.63.10 Ulpianus libro 31. ad edictum

265. D 17.2.64 Callistratus libro primo qaestionom

266. D 17.2.65 pr. Paulus libro 32. ad edictum

267. D 17.2.65.1 Paulus libro 32. ad edictum

268. D 17.2.65.2 Paulus libro 32. ad edictum

269. D 17.2.65.3 Paulus libro 32. ad edictum

270. D 17.2.65.4 Paulus libro 32. ad edictum

271. D 17.2.65.5 Paulus libro 32. ad edictum

272. D 17.2.65.6 Paulus libro 32. ad edictum

273. D 17.2.65.7 Paulus libro 32. ad edictum

274. D 17.2.65.8 Paulus libro 32. ad edictum

275. D 17.2.65.9 Paulus libro 32. ad edictum

276. D 17.2.65.10 Paulus libro 32. ad edictum

277. D 17.2.65.11 Paulus libro 32. ad edictum

278. D 17.2.65.12 Paulus libro 32. ad edictum 
279. D 17.2.65.13 Paulus libro 32. ad edictum

280. D 17.2.65.14 Paulus libro 32. ad edictum

281. D 17.2.65.15 Paulus libro 32. ad edictum

282. D 17.2.65.16 Paulus libro 32. ad edictum

283. D 17.2.66 Gaius libro decimo ad edictum provinciāle

284. D 17.2.67 pr. Paulus libro 32. ad edictum

285. D 17.2.67.1 Paulus libro 32. ad edictum

286. D 17.2.67.2 Paulus libro 32. ad edictum

287. D 17.2.67.3 Paulus libro 32. ad edictum

288. D 17.2.68 pr. Gaius libro decimo ad edictum provinciale

289. D 17.2.68.1 Gaius libro decimo ad edictum provinciale

290. D 17.2.69 Ulpianus libro 32. ad edictum

291. D 17.2.70 Paulus libro 33. ad edictum

292. D 17.2.71 pr. Paulus libro tertio epitomarum Alfeni digestorum

293. D 17.2.71.1 Paulus libro tertio epitomarum Alfeni digestorum

294. D 17.2.72 Gaius libro secundo rerum cottidianarum sive aureorum

295. D 17.2.73 pr. Ulpianus libro primo responsorum

296. D 17.2.73.1 Ulpianus libro primo responsorum

297. D 17.2.74 Paulus libro 62. ad edictum

298. D 17.2.75 Celsus libro 15. digestorum

299. D 17.2.76 Proculus libro quinto epistularum

300. D 17.2.77 Paulus libro quarto epistularum

301. D 17.2.78 Proculus libro quinto epistularum

302. D 17.2.79 Paulus libro quarto quaestionum

303. D 17.2.80 Proculus libro quinto epistularum

304. D 17.2.81 Papinianus libro nono quaestionum

305. D 17.2.82 Papinianus libro tertio responsorum

306. D 17.2.83 Paulus libro primo manualium

307. D 17.2.84 Labeo libro sexto posteriorum a Iavoleno epitomarum

308. D 18.1.35.2 Gaius libro decimo ad edictum provinciale

309. D 18.2.1 Paulus libro quinto ad Sabinum

310. D 18.2.18 Africanus libro tertio quaestionum

311. D 19.2.25.6 Gaius libro decimo ad edictum provinciale

312. D 19.5.1 pr. Papinianus libro octavo quaestionum

313. D 19.5 .13 pr. Ulpianus libro 30 ad Sabinum

314. D 19.5.13.1 Ulpianus libro 30 ad Sabinum

315. D 21.1.1 pr. Ulpianus libro primo ad edictum aedilium curulium

316. D 21.1.1.1 Ulpianus libro primo ad edictum aedilium curulium

317. D 21.1.1.2 Ulpianus libro primo ad edictum aedilium curulium

318. D 21.1.44.1 Paulus libro secundo ad edictum aedilium curulium

319. D 22.1.1.1 Papinianus libro secundo quaestionum

320. D 22.1.38.9 Paulus libro sexto ad Plautium

321. D 24.1.1 Ulpianus libro 32 ad Sabinum

322. D 24.1.32.24 Ulpianus libro 33 ad Sabinum

323. D 24.3.54 Paulus libro singulari de iure singulari

324. D 25.2.1 Paulus libro septimo ad Sabinum

325. D 26.7.47.6 Scaevola libro secundo responsorum 
327. D 28.5.8 pr. Iulianus libro secundo ad Urseium Ferocem

328. D 28.5.8.1 Iulianus libro secundo ad Urseium Ferocem

329. D 28.5.60. (59.) 1 Celsus libro 16 digestorum

330. D 28.5.90 (89) Paulus libro secundo manualium

331. D 28.7.4 pr. Ulpianus libro octavo ad Sabinum

332. D 29.2.42.1 Ulpianus libro quarto disputationum

333. D 29.2.45.2 Iulianus libro primo ad Urseium Ferocem

334. D 32.11.21 Ulpianus libro secundo fideicommissorum

335. D 32.30.4 Labeo libro secundo posteriorum a Iavoleno epitomatorum

336. D 34.1.16 pr. Scaevola libro 18 digestorum

337. D 34.1.16.3 Scaevola libro 18 digestorum

338. D 34.3 .1 pr. Ulpianus libro 21 ad Sabinum

339. D 34.3 .3 pr. Ulpianus libro 23 ad Sabinum,

340. D 34.3.3.3 Ulpianus libro 23 ad Sabinum

341. D 34.3.3.4 Ulpianus libro 23 ad Sabinum

342. D 34.3.3.5 Ulpianus libro 23 ad Sabinum

343. D 34.3.5.1 Ulpianus libro 23 ad Sabinum

344. D 34.3.29 Paulus libro sexto ad legem Iuliam et Papiam

345. D 35.2.1 pr. Paulus libro singulari ad legem Falcidiam

346. D 35.2.62 pr. Ulpianus libro primo ad legem Iuliam et Papiam

347. D 38.1.36 Ulpianus libro 11 ad legem Iuliam et Papiam

348. D 38.2.1.1 Ulpianus libro 42 ad edictum

349. D 38.2.1.2 Ulpianus libro 42 ad edictum

350. D 38.2.2 pr. Ulpianus libro 42 ad edictum

351. D 39.2.32 Gaius libro 28 ad edictum provinciale

352. D 39.4 .1 pr. Ulpianus libro 55 ad edictum

353. D 39.4.3 pr. Ulpianus libro 55 ad edictum

354. D 39.4.3.1 Ulpianus libro 55 ad edictum

355. D 39.6.35.5 Paulus libro sexto ad legem Iuliam et Papiam

356. D 40.4.48 Papinianus libro decimo quaestionum

357. D 42.1.16 Ulpianus libro 63 ad edictum

358. D 42.1.22.1 Pomponius libro 21 ad Quintum Mucium

359. D 42.1.52 Tryphoninus libro 12 disputationum

360. D 43.9 .1 pr.Ulpianus libro 68 ad edictum

361. D 43.9.1.2 Ulpianus libro 68 ad edictum

362. D 44.1.7 pr. Paulus libro tertio ad Plautium

363. D 44.5.1.7 Ulpianus libro 76 ad edictum

364. D 44.7.1.4 Gaius libro secundo aureorum

365. D 44.7.2 pr. Gaius libro tertio institutionum

366. D 44.7.2.1 Gaius libro tertio institutionum

367. D 44.7.2.2 Gaius libro tertio institutionum

368. D 44.7.57 Pomponius libro 36 ad Quintum Mucium

369. D 45.1.140.2 Paulus libro tertio ad Neratium

370. D 45.2.2 Iavolenus libro tertio ex Plautio

371. D 45.2.9.1 Papinianus libro 27 quaestionum

372. D 45.2.10 Papinianus libro 37 quaestionum 
373. D 45.3.7.1 Ulpianus libro 48 ad Sabinum

374. D 45.3.18 pr. Papinianus libro 27 quaestionum

375. D 45.3.28.1 Gaius libro tertio de verborum obligationibus

376. D 45.3.28.3 Gaius libro tertio de verborum obligationibus

377. D 46.1.22 Florentinus libro octavo institutionum

378. D 46.1.70.5 Gaius libro primo de verborum obligationibus

379. D 46.1.71 pr. Paulus libro quarto quaestionum

380. D 46.4.8.2 Ulpianus libro 48 ad Sabinum

381. D 46.8.1 Papinianus libro 28 quaestionum

382. D 46.8.14 Paulus libro tertio ad Plautium

383. D 47.2.45 Ulpianus libro 41.ad Sabinum

384. D 47.2.52.18 Ulpianus libro 37. ad edictum

385. D 47.6 .1 pr. Ulpianus libro 38 ad edictum

386. D 47.6.1.1 Ulpianus libro 38 ad edictum

387. D 47.6.2 Iulianus libro 23 digestorum

388. D 47.6.5 Marcellus libro octavo digestorum

389. D 47.10.17.9 Ulpianus libro 57 ad edictum

390. D 47.22.1pr. Marcianus libro tertio institutionum

391. D 47.22.1.1 Marcianus libro tertio institutionum

392. D 47.22.1.2 Marcianus libro tertio institutionum

393. D 47.22.2 Ulpianus libro sexto de officio proconsulis

394. D 47.22 .3 pr. Marcianus libro secundo iudiciorum publicorum

395. D 47.22.3.1 Marcianus libro secundo iudiciorum publicorum

396. D 47.22.3.2 Marcianus libro secundo iudiciorum publicorum

397. D 47.22.4 Gaius libro quarto ad legem duodecim tabularum

398. D 48.10 .1 pr. Marcianus libro 14 institutionum

399. D 48.10.20 Hermogenianus libro sexto iuris

400. D 48.12.1 Marcianus libro secundo institutionum

401. D 48.12 .2 pr. Ulpianus libro nono de officio proconsulis

402. D 48.12.2.1 Ulpianus libro nono de officio proconsulis

403. D 48.12.2.2 Ulpianus libro nono de officio proconsulis

404. D 48.12.3.1 Papirius libro primo de constitutionis

405. D 48.18.17.2 Papinianus libro 16 responsorum

406. D 49.17.18.2 Maecenatus libro primo fideicommissorum

407. D 50.16.19 Ulpianus libro 11 ad edictum

408. D 50.16.85 Marcellus libro primo digestorum

409. D 50.16.114 Iavolenus libro 15. ex Cassio

410. D 50.16.234.1 Gaius libro secundo ad legem doudecim tabularum

411. D 50.17.23 Ulpianus libro 29 ad Sabinum

412. D 50.17.47.1 Ulpianus libro 30 ad edictum

413. D 50.17.95 Ulpianus libro sexton fideicommissorum

414. Gaius, inst. 3.148

415. Gaius, inst. 3.149

416. Gaius, inst. 3.150

417. Gaius, inst. 3.151

418. Gaius, inst. 3.152

419. Gaius, inst. 3.153 
420. Gaius, inst .3 .154

421. Gaius, inst. 4.14

422. I 2.1 .4

423. I 2.1 .6

424. I 2.1 .20

425. I 2.1 .21

426. I 2.1 .22

427. I 2.9 .1

428. I 3.25. pr.

429. I 3.25 .1

430. I 3.25 .2

431. I 3.25 .3

432. I 3.25 .4

433. I 3.25 .5

434. I 3.25 .6

435. I 3.25 .7

436. I 3.25 .8

437. I 3.25 .9

438. I 4.6 .1

439. I 4.6 .17

440. I 4.6.20

441. I 4.6 .28

442. I 4.6 .30

443. I 4.6 .38

444. I 4.7 .2

\section{National legislation}

445. Associations and Foundations Law.: LR Law, October 30, 2003 // Official journal Latvijas Vēstnesis 14.11.2003., No. 161 (2926).

446. Civil Law.: LR Law, January 28,1937, entered into force on 01.09.1992.// Official journal Valdības Vēstnesis 20.02.1937., No. 41.

447. Civil Procedure Law.: LR Law, October 14,1998 // Official journal Latvijas Vēstnesis 03.11.1998., No. 326/330 (1387/1391).

448. Criminal Law.: LR Law, June 17, 1998 // Official journal Latvijas Vēstnesis 08.07.1998. No. 199/200 (1260/1261).

449. Commercial Law.: LR Law, April 13, 2000 // Official journal Latvijas Vēstnesis 04.05.2000. No. 158/160 (2069/2071)

500. Criminal Procedure Law. : LR Law, April 21,2005 // Official journal Latvijas Vēstnesis 11.05.2005. No. 74 (3232).

\section{Bibliography}

501. Apsitis, A. (2014) The reimbursement for the medical treatment expenses within the framework of Roman Partnership Agreement (Societa), SHS WEB Conferences 10 00003, DOI: http://dx.doi.org/10.1051/shsconf/20141000003, viewed 19.09.2014. 
502. Apsītis, A.; Joksts, O. (2013.) Noziedzīgs nodarījums zādzība (furtum) romiešu tiesību kontekstā, (Offence of Theft (furtum) In The Context of Roman Law), Administratīvā un Kriminālā Justīcija., 1 (62), 7-14, 11, ISSN 1407-2971.

503. Apsītis, A.; Joksts, O. (2013) The concept of infamy (infamia) in Roman law: An engine for sustainable development and public security - the Roman example, Journal of Security and Sustainability Issues 3(1):, 32, 31-41 http://dx.doi.org/10.9770/jssi.2013.3.1(4) , 34, 33-43, ISSN 2029-7017/ISSN 2029-7025 online.

504. Birks, P.; McLeod, G. (eds.) (1987) Justinian's Institutes. Translated by Peter Birks \& Grant McLeod., Ithaca N.Y., Cornell University Press.

505. Būmanis, A. (1938.) Gaja Institūcijas. Pirmais un otrais komentārs. (Gai Institutes. The first and second commentary.) Tieslietu Ministrijas izdevums.

506. CIL 11.1147, in: Duncan-Jones, R. (1990) Structure and Scale in the Roman Economy., Cambridge University Press, 127.

507. Duncan-Jones, R. (1990) Structure and Scale in the Roman Economy, Cambridge University Press, 30.

508. Hopkins, K. (1980) Taxes and Trade in the Roman Empire (200 B.C. - A.D. 400), The Journal of Roman Studies, Vol. 70.

509. Jolowicz, H.F.; Nicholas, B. (1972) Historical introduction to the study of Roman Law, Cambrige University Press, 479 - 498.

510. Kalninš, V. (1977.) Romiešu civiltiesību pamati, (The Basics of Roman Civil Law), Rīga, 26, 35 - 62, 55 - 60, 72, 169-170, 197 - 198, 199 - 205.

511. Krueger, P. (ed.) (1906) CORPUS IURIS CIVILIS, EDITIO STEREOTYPIA OCTAVA, VOLUMEN SECUNDUM, CODEX IUSTINIANUS, RECOGNOVIT PAULUS KRUEGER, BEROLINI, APUD WEIDMANNOS, MCMVI, (Body of Civil Law, Eighth Stereotype Edition, Second Volume, The Code of Justinian, Revised by Paul Krueger, Berlin, Weidmannos, 1906) 176 - 177 etc., online: http://fama2.us.es/fde/ocr/2007/corpusIurisCivilisCodexIustinianus.pdf , 206 207 etc., viewed 31.07.2014.

512. Krueger, P.; Mommsen, T. (eds.) (1928) CORPUS IURIS CIVILIS, EDITIO STEREOTYPIA QUINTA DECIMA, VOLUMEN PRIMUM, INSTUTIONES, RECOGNOVIT PAULUS KRUEGER, DIGESTA, RECOGNOVIT THEODORUS MOMMSEN, RETRACTAVIT PAULUS KRUEGER, BEROLINI, APUD WEIDMANNOS, MCMXXVIII, (Body of Civil Law, Fifteenth Stereotype Edition, First Volume, Institutes, Revised by Paul Krueger, Digest, Revised by Theodore Mommsen, Reworked by Paul Krueger, Berlin. Weidmannos, 1928.) IUSTINIANI INSTITUTIONES (Institutes of Justinian) 40-41 etc., online: http://fama2.us.es/fde/ocr/2006/corpusIurisCivilisT1InstitutionesDigesta.pdf. 63-64 etc., viewed 31.07.2014.

IUSTINIANI DIGESTA (Digest of Justinian) 72-73, 256-262, 840 etc., online: http://fama2.us.es/fde/ocr/2006/corpusIurisCivilisT1InstitutionesDigesta.pdf. 155-156, 339 -345, 923 etc., viewed 31.07.2014.

513. Kunkel, W. (1966) An Introduction to Roman Legal and Constitutional History, Oxford, 157.

514. Plutarch, (1899) LIFE OF MARCUS CATO, XXI.5-6, PLUTARCH'S LIVES TRANSLATED FROM THE GREEK, WITH NOTES AND A LIFE OF 
PLUTARCH BY AUBREY STEWART, M.A. Late Fellow of Trinity College, Cambridge AND THE LATE GEORGE LONG, M.A. Formerly Fellow of Trinity College, Cambridge, IN FOUR VOLUMES, VOL. II., LONDON, $\begin{array}{llll}\text { GEORGE BELL } & \text { AND }\end{array}$ online:http://www.gutenberg.org/files/14114/14114-h/14114-

h.htm\#LIFE_OF_MARCUS_CATO - viewed 31.07.2014.

515. Rickman, G. (1980) The Corn Supply of Ancient Rome, Oxford, Clarendon Press, 27-28.

516. Riley, H.T.; Smart, C. (eds.) (1887) THE COMEDIES OF T E R E N C E. AND THE FABLES OF PHADRUS. LITERALLY TRANSLATED INTO ENGLISH PROSE WITH NOTES, LONDON, GEORGE BELL \& SONS, 368/476 (THE FABLES OF PHAEDRUS, Book I, Fable V,

online: http://www.gutenberg.org/files/25512/25512-h/25512-h.htm , viewed 31.07.2014.

517. Scheidel, W. (2006) Population and Demografy, Princeton/Stanford Working Papers in Clasics, Version 1.0, online:

http://www.princeton.edu/ pswpc/pdfs/schieidel/040604.pdf _ - viewed 31.07.2014.

518. Scheidel, W.; Morris, I.; Saller, R. (eds.) (2007) The Cambridge Economic History of the Greco- Roman World, Cambridge University Press, ISBN 978-0521-78053-7, 1-12.

519. Schoell, R.; Kroll, G. (eds.) (1959) CORPUS IURIS CIVILIS, EDITIO SEXTA LVCIS OPE EXPRESSA,VOLUMEN TERTIUM, NOVELLAE, RECOONOVIT RUDOLFUS SCHOELL, OPUS SCHOELLII MORTE INTERCEPTUM ABSOLVIT GUILELMUS KROLL, BEROLINI, APUD WEIDMANNOS MCMLIX, (Body of Civil Law, Sixth Corrected Edition,Third Volume, Novels, Revised by Rudolf Schoell, Late Schoell's Opus completed by Wilhelm Kroll, Berlin, Weidmannos. 1959.) 536 - 548 , 551 - 552 , online:

http://www.koeblergerhard.de/Fontes/Novellae_CorpusIurisCivilisSchoell1959. pdf , $560-572$, 575-576, viewed 31.07.2014.

520. Seckel, E.; Kuebler, B. (eds.) (1903) GAI INSTITUTIONUM COMMENTARII QUATTOUR, LIPSIAE, IN AEDIBUS B.G.TEUBNERI, MCMIII, (Gai Institutes, four commentaries, Leipzig, B.G.Teubner, 1903) 2-4, 35, 41-42, 53-54, 60, 164-166, 193, online:

http://www.archive.org/stream/gaiinstitutionu00huscgoog\#page/n6/mode/2up , viewed 31.07.2014.

521. Sirks, A. J. B. (1991) Food for Rome: the Legal Structure of the Transportation and Processing of Supplies for the Imperial Distributions in Rome and Constantinople, Amsterdam, Gieben, 25-33.

522. Temin, P. (2001) A Market Economy in The Early Roman Empire, Massachusetts Institute of Technology Departament of Economics Working Paper Series, Working paper 01-08 . online: http://econ www.mit.edu/files/1238, viewed 31.07.2014.

523. Watson, A (ed.) (1985), The Digest of Justinian [with Latin text edd. T. Mommsen and P. Krüger] , 4 vols., Philadelphia PA , University of Pennsylvania Press, ISBN 0-8122-7945-X. 